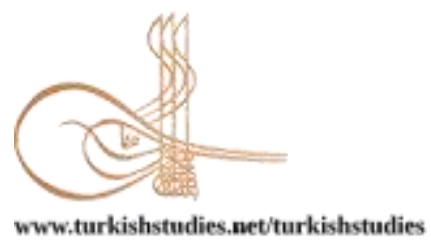

Turkish Studies

\title{
Rast ve Uşşak Makamlarına Ait Peşrevlerin Tahlili Doğrultusunda Türk Müziği Keman Eğitimine Yönelik Geçki ve Çeşni Etütlerinin Oluşturulması
}

\author{
Creation of Transition and Taste Studies for Turkish Music Violin Education in line with the \\ Analysis of Peşrevs of the Rast and Uş̧̧ak Maqams
}

\author{
Haluk Bükülmez*
}

\begin{abstract}
Peşrev form is the major form that is used to teach maqam and performance style in Turkish music. The pieces in the form of Peşrev are pieces that give information about the structure of the relevant maqam and maqam transitions. Using a teaching method based solely on the performance of the pieces does not provide the learning of transition skill and technical mastery in terms of performance within Turkish music in general and Turkish music violin education in particular. Considering the lack of materials available for Turkish music violin education, it is of great importance to create studies that will provide technical mastery with the maqam transition skills. This research aims to identify the transition, taste, âgâz (starting pitch), use of mid-pitch, and pitch range of the Peşrevs composed in Rast and Uşşak maqams; To determine the similarities and differences between the findings obtained as a result of the analysis peşrevs and the maqam descriptions in nazariyat (Turkish music theory) literature created in the 19th and 20th century; accordingly, to create studies for Rast and Uşşak maqams that will improve technical skills and maqam transition skills in Turkish music violin education. In this research, a qualitative method was adopted, and the scanning model was used. The data of the research were collected using document review, literature review, and archive scanning techniques. Based on the findings obtained, two studies have been created for each of the Rast and Uşşak maqams. The first set of studies include transition/taste use, basic rhythm patterns, basic bow techniques (Legato, Detache, Staccato), and ornamentation (Impact, Glissando, Mordan, Trill), while the second set of studies include different rhythm patterns and III. and IV. position shifting as well as basic bow techniques (Legato, Detache, Staccato) and ornamentation (Impact, Glissando, Mordan, Trill) in order to gain and/or increase technical mastery of Turkish music violin performance.
\end{abstract}

Structured Abstract: Purpose: This research aims to identify the transition, taste, âgâz (starting pitch), use of mid-pitch, and pitch range of the Peşrevs composed in Rast and Uşşak maqams; To determine the similarities and differences between the findings obtained as a result of the analysis of peşrevs and the maqam descriptions of Abdülbâki Nasır Dede, Haşim Bey and Tanburi Cemil Bey in the 19th century, and Hüseyin Sadettin Arel, Ekrem Karadeniz, and Yakup Fikret Kutluğ in the 20th century in nazariyat (Turkish music theory) literature; accordingly, to create studies that will improve technical skills and maqam transition skills in Turkish music violin education.

Method: In this research, a qualitative method was adopted, and the scanning model was used. The pieces composed in the form of peşrev in Rast and Uşşak maqams constitute the universe of the research.

*Öğr. Gör., Tekirdağ Namık Kemal Üniversitesi, Türk Müziği Devlet Konservatuvarı, Çalğı Eğitimi Bölümü Lect., Tekirdă̆ Namık Kemal University, Turkish Music State Conservatory, Department of Instrument Education, ORCID 0000-0002-3360-6629

hbukulmez@nku.edu.tr

Cite as/ Atıf: Bükülmez, H. (2021). Rast ve uşşak makamlarına ait peşrevlerin tahlili doğrultusunda Türk müziği keman eğitimine yönelik geçki ve çeşni etütlerinin oluşturulması. Turkish Studies, 16(2), 549-581. https://dx.doi.org/10.7827/TurkishStudies.49434

Received/Geliş: 15 February/Şubat 2021

Accepted/Kabul: 25 April/Nisan 2021

Checked by plagiarism software

Published/Yayın: 30 April/Nisan 2021

CC BY-NC 4.0 
Non-random purposeful sampling was used to reach the main focus of the research. Among the pieces composed in the peşrev form of both maqam, the first 10 pieces were determined with the most transition/taste, and the sample was formed. Data were obtained using document review, literature review, and archive scanning techniques in order to form the basis of the research and to achieve the predetermined objectives. The obtained data were analyzed using the categorical content analysis method for the use of transition/taste in the pieces. Categories were created to determine the transition/taste used in the pieces and the frequency of use. Peşrevs consist of sections called 'Hane'. At the end of each Hane comes the unchanging section called the 'Mülazime'. Peşrevs usually consist of four Hane and one Mülazime. As a result of the maqam analysis of the Peşrevs, the categories created for each maqam are respectively; Transition/taste used in the first Hane, transition/taste used in the Mülazime, transition/taste used in the second Hane, transition/taste used in the third Hane, transition/taste used in the fourth Hane, the âgâz pitch used to start the sequence, mid-pitch, the sound field of the entire piece. In line with these categories created, studies were created considering the style and frequency of transition/taste used in the Hanes, the âgâz pitch used to start the sequence, mid-pitch, and the tonal area of the entire piece. Each of the studies was written in sofyan style and formed in 48 bars.

Findings and Interpretations: Among the 90 pieces composed in Rast maqam 84 pieces were examined. Apart from each other, a total of 36 transition/taste usages were determined. The most used transition/taste was Rast at Yegâh. Among the 41 pieces composed in Uşşak maqam, 35 pieces were examined. Apart from each other, a total of 29 transition/taste usages were determined. The most used transition/taste was tonic Rast. When the findings of the analysis of peşrevs in Rast Maqam and the Rast Maqam descriptions from the 19th and 20th centuries were examined, it was determined that the Rast pitch was used to start the sequence. It was determined that in terms of the melodic development, Rast maqam mostly uses the tonal area between the Yegah pitch at the lowest and the Tiz Nevâ pitch at the highest. When we look at the characteristics of transition/taste used in the Rast maqam, there was no use of transition/taste expression in 19th-century edvars and theoretical pieces, and it coincides with the expressions in the description of Huseyin Saddettin Arel, one of the 20th century nazariyat approaches. When the findings of the analysis of peşrevs in Uşşak Maqam and the Uşşak Maqam descriptions from the 19th and 20th centuries were examined, it was determined that the sequence generally started by centering the Dügâh pitch. It was determined that in terms of the melodic development, Uşşak maqam mostly uses the tonal area between the Yegah pitch at the lowest and the Tiz Nevâ pitch at the highest. When we look at the characteristics of transition/taste used in the Uşşak maqam, there was no use of transition/taste expression in 19th-century edvars and theoretical pieces, and among the 20th-century nazariyat approaches it coincides with the expressions in the descriptions of Huseyin Saddettin Arel and Yakup Fikret Kutluğ. The first studies in Rast and Uşşak maqams were created by taking into account the basic rhythm patterns in order to better understand the transition/taste. The second studies in Rast and Uşşak maqams were created by taking into account the different rhythm patterns. Legato, Detache, and Staccato bow techniques and Grace Note, Mordan, Glissando, and Trill ornamentation techniques are included in the studies.

Conclusion: As a result of the analysis of the peşrevs for the Rast maqam, it was determined that the maqam generally started by centering the Rast pitch and used the tonal area between the Yegâh pitch and the Tiz Hüseyni pitch. It was revealed that there was no information about the transition/taste use of the Rast maqam in the 19th-century nazariyat books. On the other hand, it was found that in the 20th century nazariyat books, there were similarities with the descriptions given by Hüseyin Sadettin Arel and Yakup Fikret Kutluğ. Studies for the Rast maqam included transition/taste uses and technical mastery. As a result of the analysis of the peşrevs for the Uş̧̧ak maqam, it was determined that the Uşşak maqam generally started by centering the Dügâh pitch and used the tonal area between the Yegâh pitch and the Tiz Hüseyni pitch. It was revealed that there was no information about the transition/taste use of the Uşşak maqam in the 19th-century nazariyat books. On the other hand, it was found that in the 20th century nazariyat books, there were similarities with the descriptions given by Hüseyin Sadettin Arel and Yakup Fikret Kutluğ. Studies for the Uşşak maqam included transition/taste uses and technical mastery.

Keywords: Turkish music, rast and uşşak maqams, peşrev, transition-taste, violin studies

Öz: Türk müziğinde makam ve icra üslubunun öğretilmesi amacıyla kullanılan eser formlarının başında Peşrev formu gelmektedir. Peşrev formundaki eserler ilgili makamın yapısı ve makam geçkileri hakkında 
bilgi veren eserlerdir. Genelde Türk müziği ve özelde Türk müziği keman eğitimi içerisinde sadece eser icrasına dayalı bir öğretim yöntemi kullanmak icra bakımından geçki becerisinin öğrenimi ve teknik hâkimiyet kazanımı sağlamamaktadır. Türk müziği keman eğitimine yönelik mevcut materyal eksikliği de göz önünde bulundurularak makam geçki becerisi ile beraberinde teknik hâkimiyet kazanımı sağlayacak etütlerin oluşturulması büyük bir önem arz etmektedir. Bu araştırmada, Rast ve Uşşak makamlarında bestelenmiş olan peşrevlerin geçki/çeşni, âgâz ve merkez perde kullanımı, eserin bütünündeki kullanılan ses sahasını tespit etmek, daha sonra 19 ve 20. yy da oluşturulmuş olan nazariyat kaynaklarındaki makam tarifleri ile peşrevlerin tahlili neticesinde elde edilen bulgular arasında benzer ve farklı noktaları belirlemek ve bu doğrultuda Rast ile Uşşak makamına yönelik Türk müziği keman eğitiminde makam geçki becerisi ile teknik becerinin geliştirilmesi adına etütlerin oluşturulması amaçlanmaktadır. Araştırmada nitel yöntem benimsenerek tarama modeli kullanılmıştır. Araştırmanın veri toplama aşamasında doküman inceleme, kaynak tarama ve arşiv tarama teknikleri kullanılmıştır. Elde edilen bulgular doğrultusunda bahsi geçen makamlara yönelik ikişer etüt oluşturulmuştur. Birinci etütler geçki/çeşni kullanımı, temel tartım kalıpları, temel yay teknikleri (Legato, Detache, Staccato) ve süsleme tekniklerini (Çarpma, Glissando, Mordan, Tril) içerirken, ikinci etütler Türk müziği keman icracılığında teknik hâkimiyeti kazandırmak ve/veya arttırmak için geçki/çeşni kullanımı, temel yay teknikler (Legato, Detache, Staccato) ve süsleme tekniklerinin (Çarpma, Glissando, Mordan, Tril) yanında farklı tartım kalıpları ve III ile IV. konum değişikliklerini içermektedir.

Anahtar Kelimeler:Türk müziği, rast ve uşşak makamları, peşrev, geçki-çeşni, keman etütleri

\section{Giriş}

Bir toplumun kültürel yapısını, yaşayış biçimini ve tarihsel seyri içerisinde meydana gelen olayları dahi müzik eserlerinde görmek mümkündür. Çünkü tarih içerisindeki büyük iklim değişikliklerinin, göçebe yaşam biçiminin, savaşların vb. neticesinde insanoğlu hasret, ayrılık, sevinç, aşk gibi hissetmiş olduğu duygular ile müzik eserleri vücuda getirmiştir. Bu anlamda müzik, toplumun kültürel yapısını yansıtan ve koruyan bir ses mimarisidir. Bir müzik kültürünü meydana getiren özellikler, ilgili toplumu temsil etmektedir. Kültürü temsil eden müziğin özellikleri içerisinde kullanılan ses sistemi, icra ediliş biçimi, ritmik yapısı kendi içerisindeki müzik türleri ve eser formları yer almaktadır. Büyük bir tarihi geçmişe sahip olan Türk toplumunun, kendi içerisinde çeşitlilik gösteren büyük bir zenginliğe sahip kendine has bir müzik kültürü vardır. Türk müziği kültürü, kullanılan perdeler, makam, usûl, formlar (saz, söz vb.) ile büyük bir zenginlik içermektedir.

$\mathrm{Bu}$ zenginlik içerisindeki müzik mirasımızın kendine has özelliklerini ve değerlerini kaybetmeden gelecek kuşaklara aktarmak Türk müziği kültürünün korunması anlamında büyük bir önem arz etmektedir. Gerek çalgı müziğini meydana getiren çalg1 icracılığının eğitimi gerekse sözlü müzik içerisindeki ses icracılığının eğitimi fark etmeksizin Türk müziği eğitiminin tarihsel sürecine bakıldığında müziğin kuşaktan kuşağa aktarılmasında kullanılan yöntemlerin başında meşk sistemi gelmektedir. Meşk sisteminde usta-çırak ilişkisi ile beraber eser icrasına dayalı bir yöntem kullanılmaktadır. Bu yöntem ile gerçekleştirilen müzik eğitimi neticesinde çırak olarak adlandırılan kişi Türk müziği üslubu, eserin ait olduğu makamın yapısı, makamı oluşturan unsurları (seyir, geçki vb.) ve Türk müziği usûlleri hakkında bilgi edinirken bunun yanı sıra Türk müziği içerisindeki repertuvar bir sonraki kuşağa aktarılmış olur. Meşk sistemi içerisinde aynı zamanda kişi âdâb-1 muaşeret hususunda bilgi edinerek sanatçı kişiliğine yakışan davranış biçimi hakkında da bilgi sahibi olurdu. "Âdâb-1 muaşeret konusu, eski yüzyıllarda yazılmış musiki kitaplarında da yer alır ve genellikle 'âdâb-1 mecâlis' olarak geçer. Kitapların bu fasıllarında, musiki talebesinin cemiyet içerisindeki uyması gereken davranış biçimleri anlatılır” (Bardakçı, 2012: 40). 20. yy Türk müziğinin önemli bestekâr ve icracılarından biri olan Refik Fersan'ın radyo sınavını kazanan kişiler için hazırlamış olduğu müzik eğitimi programlarında dahi âdâb-1 muaşeret başlığında bir dersin yer aldığı görülmektedir (Bardakçı, 2012: 40-41). Ancak meşk sistemi birçok fayda sağlayan unsurlarının yanı sıra müziğin aktarılma süreci içerisinde bazı eksiklikleri de beraberinde getirmektedir. "Bu kusurların en erken farkına varılanı ve özellikle 19. yüzyıl sonlarından itibaren 
sıkça dile getirileni eser kayıplarıyla ilgilidir" (Behar, 2012: 161). "Bir diğeri ise; meşk, repertuvar öğrenimiyle teknik öğrenimi ayırt etmez" (Behar, 2012: 172) olmasıdır. "Taklit ve tekrar sürecinde amaç var olanı nakletmek olduğundan saza yönelik teknik beceriler göz ardı edilerek geliştirmesine olanak sağlayacak herhangi bir yazılı materyal uzun yıllar oluşturulmamıştır" (Hatipoğlu, 2016: 424). Zaman içerisinde eserlerin unutularak bestekârın bestelemiş olduğu halinin değişime uğraması, usta olarak adlandırılan kişinin bilgi, beceri ve tecrübesi doğrultusunda eğitim vermesi ve eser icrası ile gerçekleştirilen yöntem içerisinde teknik hakimiyet üzerine bir çalışma yer almaması bu eğitim sisteminin en önemli eksiklikleri olarak görülmektedir.

"Genelde Türk müziği icra geleneğinin öğretimine yönelik bu sorunların özelde Türk müziği keman eğitim-öğretim sürecinde de var olduğu bilinmektedir” (Hatipoğlu, 2013: 1). Türk müziği keman eğitimine yönelik yazılı kaynakların azlığı Türk müziği keman icracılarını ve Türk müziği keman eğitimcilerini Batı müziği keman eğitimine yönelik mevcut kaynakları kullanmaya yöneltmiş ancak bu durum Türk müziği keman icracılığına uyarlanamamıştır. "Kemanın Türk müziğindeki icra ediliş biçimi, başka bir değişle Türk müziğindeki keman icra üslubu, Türk müziği saz icracılığında sıkça kullanılan ve önemli bir işleve sahip olan bir kavramdır" (Bükülmez, 2019: 10). Ancak Türk müziği keman eğitimine yönelik mevcut kaynaklara bakıldığında materyal sayısının oldukça az olduğu görülmektedir. "Tespit edilen keman öğretimine yönelik oluşturulmuş öğretim kaynakları şunlardır: 1) Kemani Zarifaki'nin 'Alaturka Keman Muallimi, 2) Seyyid Yakûb Hânzade Seyyid Abdülkadir - Abdülkadir Töre'nin 'Usûl-i Ta'lim-i Keman', 3) Mustafa Sunar'ın 'Alaturka Keman Muallimi, 4) Mildan Niyazi Ayomak Keman Dersleri, 5) Aydın Nafiz Oran'ın 'Keman Metodu-Türk Müziğinde Keman İcra, Teknik ve Sanatı',6) Mehmet Akpınar'ın 'Keman Eğitimi İçin Makamsal Ezgiler Albümü', 7) Aydın Özden'in Türk Müziğinde Keman Metodu, 8)Vasfi Hatipoğlu'nun Beylik Aranağme ve Çeşitlemeleriyle Türk Müziği Keman Alıştırmaları 9) Mehmet Akpınar'ın Keman İçin Türküler" (Hatipoğlu, 2018: 606-607). "Eldeki Türk müziği keman öğretim kitaplarının sayısal bakımdan azlığı keman sazıyla ortaya konulan Türk müziği icra üslubunun örgün eğitim yoluyla öğretimini sorunlu hale getirmiştir” (Hatipoğlu, 2017: 5). Bu bilgilerden yola çıkarak Türk müziği keman icra üslubunun korunması, kuşaktan kuşağa aktarılması, teknik hâkimiyetin kazandırılması ve/veya arttırılması için kişilerin icra seviyesine göre farklılık gösteren birçok materyal oluşturulması gerekliliği görülmektedir.

Genelde Türk müziği eğitimi, özelde ise Türk müziği keman eğitimi içerisinde en önemli unsurlardan biri makamların öğrenimi ve icra ediliş sürecidir. Bu süreç içerisinde nazariyat ve icra dersleri yer almaktadır. Makamların eser icrası ile tanıtılması amacıyla kullanılan Türk müziği eser formlarının başında Peşrev formu gelmektedir. Peşrevler hem bestelenmiş olduğu makam hakkında hem de makam geçkileri hakkında bilgi veren eserlerdir. Genellikle 4 hane ve 1 Mülazime bölümlerinden oluşan peşrev formunu, en az 2 hane veya 4'ten daha fazla haneleri olan eserler ile de görmek mümkündür. "Peşrevler şöyle bestelenir: Birinci hanenin yarısı yahut üçte biri, yahut dörtte biri Terci-i Bend'dir ki, sazendeler buna Serbend derler. Bu kısım peşrevin her hanesinin sonunda tekerrür eder. Peşrev, ekseriya Remel yahut Muhammes usûlleriyle bestelenir. Diğer usûllerle de bestelemek mümkündür" (Özalp, 2000: 128). "Peşrevlerde haneler bestelendiği makamın sesle ilgili seyir ve hareketlerini gösteren ezgiler ve o makamın icabettirebileceği geçkilerle bezenmiştir" (Özalp, 2000: 129). Peşrevlerin 1. hane ve Mülazime bölümü içerisindeki yer alan ezgiler, peşrevin bestelenmiş olduğu makamın kısaca bir tarifi niteliğindedir. Genellikle 2. hane içerisinde yakın veya uzak bir geçki/çeşni kullanımı, 3. hane içerisinde seyrin tiz bölgede işlenmesi ile yakın veya uzak geçki/çeşni kullanımı ve 4 . hane içerisinde ise yakın veya uzak geçki/çeşni kullanımı ile asıl makamın seyrine dönüş yer almaktadır. Makamı meydana getiren unsurlar arasında geçki/çeşni kullanımının da büyük bir öneme sahip olduğu görülmektedir. Örneğin; Rast makamına ait bir eser yahut bir taksim icrası dinlenildiği zaman icranın Dügâh perdesinde Uşşak'lı kalış yapma gerekliliği Rast makamına aşikâr kişiler tarafından bilinmektedir. "Peşrevlerin ikinci, üçüncü, dördüncü hanelerinde bestekarın nazari bilgisi ve duygu zenginliği sınırları içinde çeşitli makam geçkileri ve müzik sanatı ile ilgili süslemeler yer alır” (Özalp, 1992: 
6-7). Ancak ilgili makama ait eserler içerisinde kullanılan geçki/çeşniler bestekârın bilgi ve tecrübesine bağlı olup, teknik hâkimiyet kazandırmayı yahut arttırmaya yönelik unsurları içermemektedir. Bunun yanı sıra her eser içerisinde makam geçkisinin yer almaması, Peşrevlerdeki makam geçkisinin bestekârın müzik bilgisi ile duygu zenginliği çerçevesinde oluşması, makam geçkilerine yönelik yeterli kuramsal kaynağın mevcut olmaması ve meşk sisteminin eksik kalan yönlerinden bahsedilirken değinildiği gibi Türk müziğine ait her eser icrası teknik kazanıma yol açmaması Türk müziği keman icracılığında ve öğreniminde büyük bir güçlük meydana getirmektedir.

Çalg1 eğitimi sürecinde eğitimin sistematik bir çerçevede gerçekleştirilmesine, icrasını kolaylaştırıcı ve müzikal olarak çalgısını daha iyi bir ifade aracı olarak kullanması amacıyla teknik hakimiyetin kazandırılması veya arttırılmasına yönelik metot kullanımı önemli bir yer tutmaktadır. "İlk konservatuvarlardan günümüze kadar süre gelen eğitim sürecinde icracının iyi yetişmesi ve sağlam bir teknik kazanması amacıyla birçok metot yazılmıştır” (Şen, 1992: 4). Tabii olarak Türk müziği eğitimi içerisinde de sadece bestelenmiş olan eserlerin materyal olarak kullanılmaması bunun yanı sıra kişilere, icra seviyelerine, yaş gruplarına, Türk müziğini meydana getiren konuların ayrı ayrı olarak ele alınış biçimine yönelik farklı materyallerin oluşturulması Türk müziği çalgı eğitiminin gelişimine katkı sağlayacaktır.

Bir konuda edinim kazanmak için ilgili konuyu içeren ve sürekliliği olan bir çalışma yapılması gerekmektedir. Eğitim içerisinde bu hususa hizmet eden en önemli kavram ise etütlerdir. Etüt kavramı öncelikle ilgili konunun etüt edilmesi ve ardından sahada uygulanması bakımından sadece müzik içerisinde değil birçok branşta yer alarak büyük bir öneme sahiptir. Özellikle çalg1 eğitimi konusuna yönelik mevcut materyal eksikliği, icracılar arasında çalgı tutuşu, çalgıdan doğru ses üretimi gibi genel konularda dahi farklılıklar meydana getirmektedir. Çalgı eğitimi sürecinde eğitimin sistematik bir hale dönüşmesi ve hedeflenen edinimlerin kazanılmasına yönelik etütlerin oluşturulmasının büyük bir öneme sahip olduğu görülmektedir.

$\mathrm{Bu}$ tespitler doğrultusunda; Türk müziği keman eğitiminde Türk müziği unsurlarının devamlılığını sağlamak amacıyla; (1) eğitimde hem kendi kültürüne ait müzik icrasına hem de teknik çalışmaya yönelik kaynak oluşturulmuş, (2) makamın işlenişindeki geçki /çeşnilere yönelik kuramsal bilgiler ile eserlerdeki kullanılış biçimini karşılaştırarak benzerlik ve farklılıkları tespit edilmiş ve (3) belirlenen mütedavil makamlarda bestelenen peşrevlerde yer alan geçki/çeşnilerin tahlili doğrultusunda Türk müziği keman eğitiminde teknik çalışmalar ile geçki/çeşni çalışmaların birlikte yer aldığı etütler oluşturulmuştur. Oluşturulan etütler ilgili makama ait geçki/çeşni kullanımı bilgisinin ve teknik hakimiyetin kazanılması neticesinde icracının gerek eser gerekse taksim icralarına katkı sağlayacaktır.

\subsection{Amaç}

$\mathrm{Bu}$ araştırmada; Rast ve Uşşak makamlarına yönelik peşrev formundaki eserlerde yer alan geçki/çeşni, âgâz perde ve merkez perde kullanımları ile eserin bütünündeki ses sahalarını tespit etmek, daha sonra 19. yy da Abdülbâki Nasır Dede, Haşim Bey ve Tanburi Cemil Bey'e ait; 20. yy da ise Hüseyin Sadettin Arel, Ekrem Karadeniz ve Yakup Fikret Kutluğ'a ait nazariyat kaynaklarındaki makam tarifleri ile peşrevlerin tahlili neticesinde elde edilen bulgular arasında benzer ve farklı noktaların tespiti ve bu doğrultuda Türk müziği keman eğitiminde makamsal geçki becerisi ile teknik becerinin geliştirilmesine yönelik etütlerin oluşturulması amaçlanmaktadır.

\section{Yöntem}

Bu bölümde, araştırmanın modeli, evren ve örneklemi, araştırmada kullanılan veri toplama teknikleri, verilerin toplanması ve verilerin analizi açılanmıştır. 


\title{
2.1. Araştırmanın Modeli
}

Araştırmada Rast ve Uş̧̧ak makamlarına yönelik Peşrev formundaki eserlerde yer alan geçki/çeşnilerin tespit edilmesi, sonrasında elde edilen bu bulgular ile nazariyat kitaplarındaki tariflerin benzer ve farklı noktalarının tespiti ve keman eğitim - öğretimine özgü etütlerin oluşturulabilmesi amacıyla nitel araştırma yöntemi ve tarama modeli kullanılmıştır.

Nitel araştırma sosyal ya da beşeri bir probleme dayalı olarak bireylerin veya grupların atfettiği anlamları keşfetme ve anlamaya yönelik bir yaklaşımdır (Creswell, 2014). Nitel araştırma "gözlem, görüşme ve doküman analizi" gibi veri toplama yöntemlerinin kullanıldığı, algıların ve olayların doğal ortamda gerçekçi ve bütüncül bir biçimde ortaya koyduğu nitel süreçlerin izlendiği araştırmalar olarak tanımlanabilir (Yıldırım \& Şimşek, 2011). Ayrıca nitel yöntemler metin ve imgesel verilere dayanarak veri analizinde özgün adımlara ve kendine özgü desenlere sahip yöntemlerdir (Creswell, 2014). Tarama modeli ise;

\begin{abstract}
"Geçmişte ya da şu anda mevcut bir durumu var olduğu şekliyle betimlemeyi amaçlayan bir araştırma modelidir. Bu modelde araştırma konusu, mevcut koşulları içinde ve olduğu gibi tanımlanmaya çalışılır. Araştırılacak olaya, bireye ya da nesneye değiştirme ya da etkileme gibi herhangi bir müdahale yapılamaz. Tarama araştırmacısı nesnenin ya da bireyin doğrudan kendisini inceleyebileceği gibi, önceden tutulmuş çeşitli kayıtlara (yazılı belge, istatistikler, resimler, ses ve görüntü kayıtları vb.) eski kalıntılar ve alandaki kaynak kişilere başvurarak, elde edeceği dağınık verileri, kendi gözlemleri ile bir sistem içinde bütünleştirerek yorumlamak durumundadır" (Karasar, 2005: 77).
\end{abstract}

\subsection{Evren ve Örneklem}

Araştırmanın evrenini; Rast ve Uşşak makamının Türk müziğinde en sık kullanılan makamlar içerisinde yer almaları ve her iki makamı meydana getiren perdelerin benzerliği sebebiyle bahsi geçen makamlara ait peşrev formunda bestelenmiş eserler oluşturmaktadır.

Çizelge 1: Araştırmanın Evreni ${ }^{1}$

\begin{tabular}{lll}
\hline Sıra No & Makam İsmi & TSMSSER'deki Eser Sayısı \\
\hline $\mathbf{1}$ & Rast & 1443 \\
$\mathbf{2}$ & Uşşak & 1293 \\
\hline
\end{tabular}

Araştırmanın temel odağına ulaşmak için seçkisiz olmayan amaçlı örnekleme türü kullanılarak evrende yer alan iki makama ait peşrev formunda bestelenmiş olan eserlerin içerisinden en çok geçki/çeşni kullanılan ilk 10 (on) eser belirlenmiş ve örneklem oluşturulmuştur.

“Amaçsal (amaçl1) örnekleme, olası olmayan seçkisiz olmayan bir örnekleme yaklaşımıdır. Amaçsal örnekleme, çalışmanın amacına bağlı olarak bilgi açısından zengin durumların seçilerek derinlemesine araştırma yapılmasına olanak tanır. Belli ölçütleri karşılayan veya belli özelliklere sahip olan bir veya daha fazla özel durumlarda çalışmak istenildiğinde tercih edilir" (Büyüköztürk, Çakmak, Akgün, Karadeniz, Demirel, 2014: 90)

Amaçlı seçim kullanılarak oluşturulan örneklem kümesine Çizelge 2'de yer verilmiştir.

\begin{tabular}{lllll}
\multicolumn{5}{c}{ Çizelge 2: Örneklem Kümesi } \\
\hline Makam & Eser Sıra No & Bestekâr & $\begin{array}{l}\text { Geçki } \\
\text { Sayısı }\end{array}$ & Çeşni \\
& & & 27 & \\
2 & Edhem Efendi & 23 & \\
3 & Muzaffer & 22 & \\
\hline
\end{tabular}

\footnotetext{
${ }^{1}$ Sarisaray, 2010, s. $17-47$.
} 


\begin{tabular}{llll}
\hline \multirow{2}{*}{ Rast } & 4 & Sirrı Abdülbaki Dede & 21 \\
& 5 & Mehmet Dede & 19 \\
& 6 & Melekzet & 19 \\
& 7 & Osman Dede & 16 \\
& 8 & Ali Dede & 15 \\
& 9 & Raşit Efendi & 15 \\
& 10 & Mehmet Çelebi & 15 \\
\hline Uşşak & 1 & Bestekârı Belirli Olmayan & 22 \\
& 2 & Bestekârı Belirli Olmayan & 20 \\
& 3 & Osman Bey & 18 \\
& 5 & Farabi & 14 \\
Ușşak & 8 & Bestekârı Belirli Olmayan & 13 \\
(devamı $)$ & 7 & Haydar Tatliyay & 12 \\
& 9 & Tatyos Efendi & 12 \\
& 10 & Sultan I. Mahmud & 11 \\
\hline
\end{tabular}

\subsection{Veri Toplama Teknikleri}

Araştırmanın temelini oluşturabilmek ve önceden belirlenen amaçlara ulaşabilmek amacıyla doküman inceleme, kaynak tarama, arşiv tarama veri toplama teknikleri kullanılarak veriler elde edilmiştir.

"Doküman incelemesi, araştırılması hedeflenen olgu veya olgular hakkında bilgi içeren yazılı materyallerin analizini kapsar. Nitel araştırmada doküman incelemesi tek başına bir veri toplama yöntemi olabileceği gibi diğer veri toplama yöntemleri ile birlikte de kullanılabilir" (Yıldırım \& Şimşek, 2011: 187).

Varolan kayit ve belgeleri inceleyerek veri toplamaya kaynak tarama denir. Tarananlar: geçmișteki olguların anında iz bıraktığı resim, film, plak, ses ve resim kayıtlı bantlar, araç-gereç, bina heykel, vb. kalıntılarla; olgular hakkında sonradan yazılmış ve çizilmiş her türlü mektup, rapor, kitap, ansiklopedi, resmi ve özel yazı ve istatistikler, tutanak, anı, yaşam öyküsü vb. leridir (Karasar, 2005: 183).

$\mathrm{Bu}$ çalışmada ilk olarak Rast ve Uşşak makamına yönelik bestelenmiş olan peşrev formundaki eserlere ulaşabilmek amacıyla TRT ve Cumhurbaşkanlığı devlet korosu arşivi taranmıştır. Daha sonra 19. yy da Abdülbâki Nasır Dede, Haşim Bey ve Tanburi Cemil Bey'e ait; 20. yy da ise Hüseyin Sadettin Arel, Ekrem Karadeniz ve Yakup Fikret Kutluğ'a ait nazariyat kitaplarındaki makam tarifleri ile peşrevlerin tahlili neticesinde elde edilen bulgular arasında benzer ve farklı noktaların tespiti için kaynak tarama ve doküman incelemesi teknikleri kullanılmıştır.

\subsection{Verilerin Analizi}

Çalışmada doküman inceleme, kaynak tarama ve arşiv tarama sonucu elde edilen veriler eserlerde geçki/çeşni kullanımına yönelik içerik analizi yönteminin kategorisel türü kullanılarak analiz edilmiştir.

"İçerik analizi, çeşitli metinlerin içeriğini, naif bir okumaya kendini doğrudan vermeyen temel öğelerini sinıflandırmak ve yorumlamak amaciyla metodik, sistematik, objektif ve mümkünse nicel olarak incelenmesini sağlayan tekniktir" (Bilgin, 2006: 2). "İçerik analizinde temel amaç, toplanan verileri açıklayabilecek kavramlara ve ilişkilere ulaşabilmektir. Betimsel analizde özetlenen ve yorumlanan veriler, içerik analizinde daha derin bir işleme tabi tutulur ve betimsel bir yaklaşımla fark edilemeyen kavram ve temalar bu analiz sonucu keşfedilir" (YıldırımŞimşek, 2006: 227). "Kategorisel analiz ise, genel olarak, belirli bir mesajın önce birimlere 
bölünmesi ve ardından bir birimlerin, belirli kriterlere göre kategoriler halinde gruplandırılmasını ifade eder. Kategorilerin homojen, ayırt edici, objektif olması, bütünsellik taşıması, amaca uygun ve anlamlı olması gerekir" (Bilgin, 2006: 19).

Eserler içerisindeki kullanılan geçki/çeşnilerin tespit edilmesi ve kullanım sıklığının sınıflandırılması amacıyla kategoriler oluşturulmuştur. Peşrevlerin makam tahlili sonucunda her bir makama yönelik oluşturulan kategoriler sırasıyla; 1. Hane içerisinde kullanılan geçki/çeşniler, Mülazime içerisinde kullanılan geçki/çeşniler, 2. Hane içerisinde kullanılan geçki/çeşniler, 3. Hane içerisinde kullanılan geçki/çeşniler, 4. Hane içerisinde kullanılan geçki/çeşniler, seyre başlarken kullanılmış olan âgâz perde ve merkez perde ile eserin bütünündeki ses sahasıdır. Oluşturulan bu kategoriler doğrultusunda haneler içerisinde kullanılan geçki/çeşni kullanım sıklığı ve geçki/çeşnilerin kullanım biçimi, seyre başlarken kullanılmış olan âgâz perde ve merkez perde ile eserin bütünündeki ses sahası dikkate alınarak etütler oluşturulmuştur. Peşrevlerin tahlil basamakları ve etütlerin oluşturulma basamaklarına aşağıda yer verilmiştir.

\subsubsection{Peşrevlerin Tahlil Basamakları}

Rast ve Uşşak makamına ait peşrev formundaki eserlere Cumhurbaşkanlığı Devlet Korosunun resmî sitesinden ulaşılmıştır. Bahsi geçen makamlara ait peşrev formunda bestelenmiş toplam 131 (yüz otuz bir) eser olduğu tespit edilmiştir. Ancak 119 (yüz on dokuz) eserin nüshalarına ulaşılmıştır. Her iki makama ait peşrev formundaki eserler listelendikten sonra bestekârların eserler içerisinde kullanmış oldukları geçki/çeşni sayılarını tespit etmek amacıyla ilgili makamın seyri incelenmiş ve daha sonra geçki/çeşni sayıları kullanım sıklıkları doğrultusunda sıralanmıştır. Her makam için uygulanan sıralama içerisinde en çok geçki/çeşni kullanılmış olan ilk 10 (on) eser örneklem olarak ele alınmış ve eserlerdeki geçki/çeşni kullanımı, seyre başlarken kullanılmış olan âgâz perde ve merkez perde, eserin bütünündeki ses sahası detaylı olarak açıklanmıştır. İlgili eserlerin nüshaları üzerinde yapılan tahlillerde, geçki/çeşnilerin kullanıldığı ölçüler tespit edilmiş ve bestekârın eser içerisinde kaç adet geçki/çeşni kullandığı saptanmıştır. Eserler içerisinde ilgili makamı oluşturan çeşnilerin haricinde kullanılan diğer çeşniler, makamı meydana getiren perdelerin haricinde kullanılan diğer perdeler dikkate alınmış ve kalış yapılan perdelerde göz önünde bulundurularak eser içerisinde kullanılan geçki/çeşniler tespit edilmiştir. Örneğin; Rast makamında Edhem Efendi'nin bestelemiş olduğu peşrevin yedinci dizeğinde makamı meydana getiren perdelerin haricinde Nim Hicaz ve Dik Kürdi perdeleri kullanılarak yerinde Nikriz'li geçki/çeşni kullanılmıştır (Örnek 1). Veyahut Mehmet Çelebi'nin Rast makamında bestelemiş olduğu peşrevin on dördüncü dizeğinde Dügâh perdesinde kalış yaparak yerinde Uşşak'lı geçki/çeşni kullanılmıştır (Örnek 2).

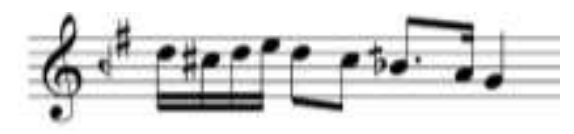

Örnek 1

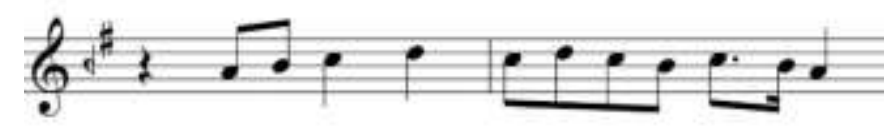

Örnek 2

Bestekârların eserin başlangıcında kullanmış oldukları motifler incelenerek seyre başlangıcındaki âgâz perdesi ve merkez perde, eserin bütününde kullandıkları en pest ve en tiz ses dikkate alınarak eserlerin ses sahaları belirlenmiştir. Her bir makamın örneklem kümesinde yer alan eserlerin tahlilinin ardından 10 (on) eser içerisinde yer alan ve hanelerdeki kullanım durumlarını gösteren geçki/çeşni tabloları oluşturulmuştur.

\subsubsection{Etütlerin Oluşturulma Basamakları}

Rast ve Uşşak makamları içerisinde yer alan geçki/çeşni kullanımı doğrultusunda her bir makama yönelik ikişer etüt oluşturulmuştur. Birinci etütler temel tartım kalıpları, temel yay teknikleri (Legato, Detache, Staccato) ve süsleme tekniklerini (Çarpma, Glissando, Mordan, Tril) içerirken, ikinci etütler Türk müziği keman icracılığında teknik hâkimiyeti kazandırmak ve/veya 
arttırmak için temel yay teknikler (Legato, Detache, Staccato) ve süsleme tekniklerinin (Çarpma, Glissando, Mordan, Tril) yanında farklı tartım kalıpları ve III ile IV. konum değişikliklerini içermektedir. Etütler içerisinde kullanılan yay teknikleri, süsleme teknikleri ve konum değişiklikleri, Türk müziği keman icracılığında ekol olmuş kişilerin icralarının tahlilleri doğrultusunda oluşturulmuştur ${ }^{2}$. Etütler içerisinde her hane için 8 (sekiz) ölçü kullanılmıştır. Buna göre; ilk 8 (sekiz) ölçü makamın genel bir tarifi, ikinci 8 (sekiz) ölçü 1. hane içerisinde kullanılan geçki/çeşniler, üçüncü 8 (sekiz) ölçü Mülazime içerisinde kullanılan geçki/çeşnileri, dördüncü 8 (sekiz) ölçü 2. hane içerisinde kullanılan geçki/çeşnileri, beşinci 8 (sekiz) ölçü 3. hane içerisinde kullanılan geçki/çeşnileri ve altınc1 8 (sekiz) ölçü 4. hane içerisinde kullanılan geçki/çeşnileri içermekte olup her bir etüdün bütününde 48 (kırk sekiz) ölçü kullanılmıştır. Etütlerin öznesinde geçki/çeşni çalışmasının yer alması ve etütlerin çalışılması aşamasında öğrencilerin/icracıların usûl unsuru ile ilgili ayrı bir çalışmaya gerek duymaması amacıyla Sofyan usûlü tercih edilmiştir. Etütler içerisinde oluşturulan ezgilerin ve ölçü sayılarının eşit olması amacıyla tüm etütler aynı usûl içerisinde oluşturulmuş, etütlerin bütününde de usûl değişikliği kullanılmamıştır. Finale v.26 nota yazım programı kullanılarak yazılan etütler, Sofyan usûlünün düzümlerine ve görünürlüğüne göre yazılmışıtır.

\section{Bulgular ve Yorumlar}

$\mathrm{Bu}$ bölümde içerik analizi ile elde edilen bulgulara ve bu bulgulara ait yorumlara yer verilmiştir. Araştırmanın bulguları ilgili makamlara ait başlıklar altında sunulmuştur.

\subsection{Rast Makamında Bestelenmiş Peşrevlerin Tahlili}

Rast makamına ait toplam 90 (doksan) adet peşrev bestelenmiştir. Bestelenen eserlerin listesine Ek 1'de yer verilmiştir. Rast makamında bestelenmiş olan 90 (doksan) eserden ulaşılan 84 (seksen dört) eser incelenmiştir ve en çok makam geçkisi/çeşnisi kullanan ilk 10 (on) eserde yer alan geçki/çeşni kullanımları şu şekildedir;

Çizelge 3: Rast Makamına Ait Peşrevlerde Kullanılan Geçki/Çeşniler

\begin{tabular}{|c|c|c|}
\hline Hane & Geçki / Çeşni & Bestekâr - Geçki /Çeşni Sayısı \\
\hline \multirow{10}{*}{ 1. Hane } & Yerinde Uşşak & $\begin{array}{l}\text { Edhem Efendi (1), Muzaffer (1), Sırrı Abdülbaki Dede } \\
\text { (1), Mehmet Dede (2), Melekzet (1), Osman Dede (1), } \\
\text { Ali Dede (1) }\end{array}$ \\
\hline & Yegâh'da Rast & $\begin{array}{l}\text { Edhem Efendi (1), Muzaffer (3), Sırrı Abdülbaki Dede } \\
\text { (2), Mehmet Dede (2), Melekzet (1), Osman Dede (4), } \\
\text { Ali Dede (2), Raşit Efendi (1) }\end{array}$ \\
\hline & Yerinde Segâh & $\begin{array}{l}\text { Edhem Efendi (1), Tatyos Efendi (1), Mehmet Dede (1), } \\
\text { Mehmet Çelebi (1) }\end{array}$ \\
\hline & Hüseyni Aşiran'da Uşşak & Mehmet Dede (1) \\
\hline & Rast'da Buselik & Mehmet Dede (1) \\
\hline & Yerinde Acemli Segâh & Melekzet (1) \\
\hline & Yerinde Nihavend & Mehmet Çelebi (1) \\
\hline & Nevâ'da Buselik & Melekzet (1) \\
\hline & Dügâh'da Rast & Mehmet Çelebi (1) \\
\hline & Dügâh'da Nişabur & Mehmet Çelebi (1) \\
\hline
\end{tabular}

\footnotetext{
2 Bkz. Murat Gürel; "Nubar Tekyay’ın Keman Taksimlerinin Tahlili” doktora çalışması, Haluk Bükülmez; "Haydar Tatlıyay ve Sadi Işılay’ın Keman İcralarının Tahlilil” Yüksek Lisans çalışması, S. Barış Demirdirek; "Hakkı Derman'ın Keman Taksimlerinin Tahlili ve Bu Tahliller Doğrultusunda Keman Eğitiminde Kullanılabilecek Alıştırmaların Oluşturulması” Yüksek Lisans çalışması, İsmail Kabacı; “20. yüzyıl Türk Müziği Keman İcrâ Üslûbunun Taksim İcrâları Üzerinden Tespiti ve Tahlili” Yüksek Lisans çalışması.
} 


\begin{tabular}{|c|c|c|}
\hline \multirow{5}{*}{ Mülazime } & Yerinde Segâh & Edhem Efendi (1), Tatyos Efendi (1), Raşit Efendi (1) \\
\hline & Nevâ'da Buselik & Tatyos Efendi (2) \\
\hline & Yegâh'da Rast & $\begin{array}{l}\text { Tatyos Efendi (1), Sırrı Abdülbaki Dede (1), Raşit } \\
\text { Efendi (1) }\end{array}$ \\
\hline & Hüseyni Aşiran'da Uşşak & Raşit Efendi (1) \\
\hline & Yerinde Hüzzam & Mehmet Çelebi (1) \\
\hline \multirow{9}{*}{ 2. Hane } & Yerinde Segâh & $\begin{array}{l}\text { Edhem Efendi (1), Tatyos Efendi (1), Mehmet Dede (2), } \\
\text { Melekzet (1), Osman Dede (1) }\end{array}$ \\
\hline & Çargâh'da Çargâh & Edhem Efendi (1) \\
\hline & Yegâh'da Rast & Edehem Efendi (1), Sırrı Abdülbaki Dede (1), Mehmet \\
\hline & & $\begin{array}{l}\text { Dede (1), Osman Dede (1), Ali Dede (1), Raşit Efendi } \\
\text { (1) }\end{array}$ \\
\hline & Yerinde Hüzzam & Edhem Efendi (1), Tatyos Efendi (2), Mehmet Çelebi (1) \\
\hline & Eviç'de Eviç/Segâh & Edhem Efendi (1) \\
\hline & Yerinde Nikriz & Edhem Efendi (1), Muzaffer (3), Osman Dede (1) \\
\hline & Hüseyni'de Uşşak & Muzaffer (1) \\
\hline & Yerinde Araban & Tatyos Efendi (1) \\
\hline \multirow{11}{*}{ 2. Hane (devami) } & Çargâh'da Nikriz & Tatyos Efendi (1) \\
\hline & Yerinde Suzinak & Tatyos Efendi (1) \\
\hline & Acem Aşiran'da Çargâh & Sirrı Abdülbaki Dede (2) \\
\hline & Yerinde Sabâ & Sırrı Abdülbaki Dede (1), Mehmet Çelebi (1) \\
\hline & Yerinde Uşşak & $\begin{array}{l}\text { Sırrı Abdülbaki Dede (1), Mehmet Dede (3), Ali Dede } \\
\text { (2), Raşit Efendi (1), Mehmet Çelebi (1) }\end{array}$ \\
\hline & Yerinde Nihavend & Mehmet Dede (1) \\
\hline & Nevâ'da Buselik & Melekzet (2), Raşit Efendi (1) \\
\hline & Gerdaniye 'de Buselik & Melekzet (1) \\
\hline & Yerinde Pençgah & Melekzet (1) \\
\hline & Yerinde Müstear & Mehmet Çelebi (1) \\
\hline & Çargâh'da Hicaz & Mehmet Çelebi \\
\hline \multirow{14}{*}{ 3. Hane } & Hüseyni'de Uşşak & Edhem Efendi (1) \\
\hline & Yerinde Segâh & $\begin{array}{l}\text { Edhem Efendi (2), Tatyos Efendi (2), Sırrı Abdülbaki } \\
\text { Dede (1) }\end{array}$ \\
\hline & Yerinde Nikriz & Muzaffer (1), Ali Dede (1), Raşit Efendi (1) \\
\hline & Yerinde Uşşak & $\begin{array}{l}\text { Muzaffer (1), Tatyos Efendi (1), Sirrı Abdülbaki Dede } \\
\text { (1), Osman Dede (1), Ali Dede (1) }\end{array}$ \\
\hline & Nevâ'da Uşşak & Tatyos Efendi (1) \\
\hline & Yerinde Nihavend & Sirrı Abdülbaki Dede (2) \\
\hline & Yegâh'da Rast & Sırrı Abdülbaki Dede (1), Osman Dede (1), Ali Dede (1) \\
\hline & Yerinde Irak & Sırrı Abdülbaki Dede (1) \\
\hline & Hüseyni Aşiran'da Uşşak & Sirrı Abdülbaki Dede (1), \\
\hline & Nevâ'da Rast & Sırrı Abdülbaki Dede (1) \\
\hline & Gerdaniye'de Buselik & Melekzet (1), Raşit Efendi (2) \\
\hline & Yerinde Rahat-ül Ervah & Melekzet (1) \\
\hline & $\begin{array}{l}\text { Hüseyni } \quad \text { Aşiran’de } \\
\text { Karcığar }\end{array}$ & Melekzet (1) \\
\hline & Nevâ'da Buselik & Melekzet (1), Ali Dede (1) \\
\hline
\end{tabular}




\begin{tabular}{|c|c|c|}
\hline & Yerinde Araban & Mehmet Çelebi (1) \\
\hline & Eviç’de Eviç/Segâh & Mehmet Çelebi (1) \\
\hline & Hüseyni'de Sabâ & Mehmet Çelebi (1) \\
\hline \multirow{14}{*}{ 4. Hane } & Nevâ'da Buselik & Edhem Efendi (1), Osman Dede (1) \\
\hline & Yerinde Nişaburek & Edhem Efendi (1) \\
\hline & Yegâh'da Rast & Edhem Efendi (1), Ali Dede (1) \\
\hline & Yerinde Hicaz & Muzaffer (4) \\
\hline & Yerinde Nikriz & Muzaffer (2), Tatyos (1), Melekzet (1), Raşit Efendi (1) \\
\hline & Yerinde Segâh & Tatyos Efendi (2), Osman Dede (1) \\
\hline & Dik Hisar'da Müstear & Tatyos Efendi (1) \\
\hline & Çargâh'da Nikriz & Melekzet (1) \\
\hline & Rast'da Hicaz & Melekzet (2) \\
\hline & Gerdaniye'de Buselik & Osman Dede (1) \\
\hline & Yerinde Uşşak & Ali Dede (1) \\
\hline & Yerinde Şedd-i Araban & Raşit Efendi (1) \\
\hline & Nevâ'da Hicaz & Mehmet Çelebi (1) \\
\hline & Eviç'de Eviç/Segâh & Mehmet Çelebi (1) \\
\hline
\end{tabular}

\subsection{Uşşak Makamında Bestelenmiş Peşrevlerin Tahlili}

Uşşak makamına ait toplam 41 (kırk bir) adet peşrev formunda eser bestelenmiştir. Bestelenen eserlerin listesine Ek 2'de yer verilmiştir. Uşşak makamında bestelenmiş olan 41 (kırk bir) eserden ulaşılan 35 (otuz beş) eser incelenmiştir ve en çok makam geçkisi/çeşnisi yapılan ilk 10 (on) eserde yer alan geçki/çeşni kullanımları şu şekildedir;

Çizelge 4: Uşşak Makamına Ait Peşrevlerde Kullanılan Geçki/Çeşniler

\begin{tabular}{|c|c|c|}
\hline Hane & Geçki / Çeşni & Bestekâr - Geçki /Çeşni Sayısı \\
\hline \multirow{4}{*}{ 1. Hane } & Yegâh'da Rast & $\begin{array}{l}\text { Bestekârı Belirli Olmayan (1), Bestekârı Belirli Olmayan } \\
\text { (1), Osman Bey (1), Farabi (1), Bestekârı Belirli } \\
\text { Olmayan (1), Tatyos Efendi (1), Sultan I. Mahmud (1) }\end{array}$ \\
\hline & Yerinde Rast & $\begin{array}{l}\text { Bestekârı Belirli Olmayan (2), Bestekârı Belirli Olmayan } \\
\text { (2), Osman Bey (3), Farabi (1), Bestekârı Belirli }\end{array}$ \\
\hline & & $\begin{array}{l}\text { Olmayan (1), Tatyos Efendi (2), Sultan I. Mahmud (1), } \\
\text { Corci (1), Salih Efendi (1) }\end{array}$ \\
\hline & Gerdaniye'de Buselik & $\begin{array}{l}\text { Bestekârı Belirli Olmayan (1), Bestekârı Belirli Olmayan } \\
\text { (1), Farabi (2) }\end{array}$ \\
\hline \multirow{8}{*}{ Mülazime } & Yerinde Rast & $\begin{array}{l}\text { Bestekârı Belirli Olmayan (1), Osman Bey (1), Farabi } \\
\text { (2), Haydar Tatliyay (1), Tatyos Efendi (1), Sultan I. } \\
\text { Mahmud (1), Corci (1) }\end{array}$ \\
\hline & Yerinde Suzinak & Haydar Tatlıyay (1) \\
\hline & Yerinde Segâh & Tatyos Efendi (1) \\
\hline & Yegâh'da Rast & Corci (1), Salih Efendi (1) \\
\hline & Yerinde Necd-i Hüseyni & Bestekâr1 Belirli Olmayan (1) \\
\hline & Yerinde Rast & $\begin{array}{l}\text { Bestekârı Belirli Olmayan (2), Bestekârı Belirli Olmayan } \\
\text { (3), Osman Bey (1), Farabi (1), Bestekârı Belirli } \\
\text { Olmayan (2), Tatyos Efendi (1), Sultan I. Mahmud (3), } \\
\text { Corci (2), Salih Efendi (1) }\end{array}$ \\
\hline & Hüseyni'de Uşşak & $\begin{array}{l}\text { Bestekârı Belirli Olmayan (1), Bestekârı Belirli Olmayan } \\
\text { (1), Farabi (1), Tatyos Efendi (2), Corci (1) }\end{array}$ \\
\hline & Yerinde Suzinak & Osman Bey (1) \\
\hline
\end{tabular}




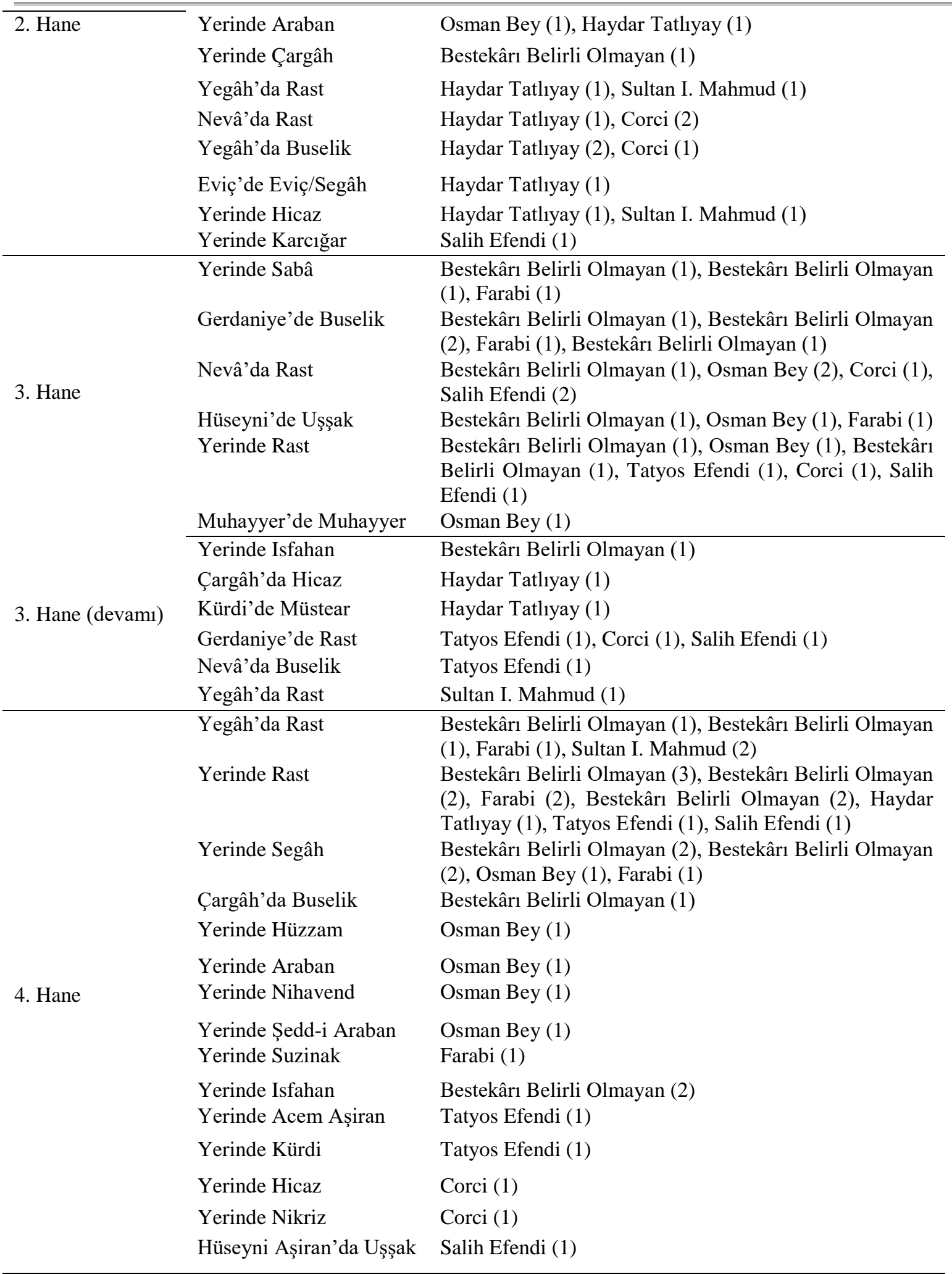

Rast makamına yönelik örneklem kümesinde yer alan 10 (on) eser incelenmiş ve eserlerin tümünde birbirinden farklı olarak toplam 36 (otuz altı) adet geçki/çeşni kullanımının olduğu görülmektedir. Rast makamı içerisinde en çok kullanılan geçki/çeşni ise Yegâh'da Rast 'tır. Uşşak makamına yönelik örneklem kümesinde yer alan 10 (on) eser içerisinde birbirinden farklı olarak 
toplam 29 (yirmi dokuz) adet geçki/çeşni kullanımının olduğu görülmekte olup makam içerisinde en çok kullanılan geçki/çeşninin ise Yerinde Rast olduğu bilgisine ulaşılmıştır.

\subsection{Nazariyat Eserlerindeki Rast Makamına Yönelik Tarifler}

\subsubsection{9. yy Nazariyat Eserlerindeki Rast Makamı Tarifleri}

\section{a-) Abdülbâki Nasır Dede}

"Rast perdesinden başlayarak, Dügâh, Segâh ve Çargâh perdesine (çıktıktan sonra) aşağı döner/ Segâh, Dügâh ve Rast perdesine gelerek burada karar verir. Ancak Çargâh (perdesinden) yukarıya doğru Nevâ, Hüseyni, Acem ve Gerdaniye perdesine; Rast perdesinden aşağı da Irak, Aşiran ve Yegâh perdesine kadar gezinir. Eskiler (Kudemâ), sonraki eskiler (Kudemâ-i Müteahhirin) ve sonrakiler (Müteahhirin) sadece (makamın perde genişliğinde), görünüşte bir ayrıllğa düşerler. Eskiler (Rasttan) Gerdaniye (perdesine) kadar (makam) dairesini oluştururken, sonraki eskiler ve sonrakiler Rasttan Yegâh'a genişleyen bu şekli kabul ettiler" (Başer, 2013: 111-112).

\section{b-) Haşim Bey}

Haşim Bey'in edvarında Rast makamına dair bir tarif bulunmamaktadır.

\section{c-) Tanburi Cemil Bey}

"Rast makamı, yedinci fasılada fa dizey nim sadasını muhtevi olmakla, sernâmesinde fa diyez işareti bulunur. Rast'ın zemini; Irak, Rast perdelerinden başlamak üzere, Gerdaniye-Yegâh arasında miyanı; Nevâ-Tiz Nevâ oktavında icra olunur. Karar dahi; Nevâ'dan ibtidar etmekten ibaret bir farkla, zeminin aynıdır. Ses veya alât-1 mûsikîyye müsaid ise, Rast miyanı Tiz Gerdaniye'ye kadar tevatür edebilir" (Cevher, 1992: 40).

\subsubsection{0. yy Nazariyat Eserlerindeki Rast Makamı Tarifleri}

\section{a-) Hüseyin Sadettin Arel}

"Durağı; Rast perdesidir. Seyri; Çıkıcıdır. Dizisi; Yerinde Rast beşlisine Nevâ'da bir Rast dörtlüsünün eklenmesinden meydana gelmiştir. Güçlüsü; Nevâ perdesidir. Asma karar perdeleri; Dügâh perdesinde Uşşak çeşnisi, Segâh perdesi üzerinde Ferahnak beşlisi veya Segâh'a Acem perdesi kullanılarak iniliyorsa eksik Ferahnak beşlisi ile de asma karar yapılabilir. Şüphesiz ki istenirse Dik Hisar perdesini kullanmak şartıyla Segâh'da Segâh çeşnisiyle kalınabilir. Bunların dışında bir asma karar yeri de Yegâh perdesidir. Genişleme sırasında asma karar perdesi olan Yegâh'da Rast çeşnisi ile asma karar yapılır. Hüseyni Aşiran'da Uş̧̧ak'lı veya Nişabur'lu kalınabilir. Genişlemesi; Rast makamı çıkıcı ve ağır başıı bir makamdır. Bu sebeple genişlemesi pest taraftan, durağın altından olur. Bu da güçlü Nevâ üstündeki Rast dörtlüsü simetrik olarak Yegâh üstüne göçürülmekle yapılır. Rast makamı aslında tiz taraftan genişletilmemiştir. Fakat seyrek de olsa nağmeler tiz durağı aşarsa hangi seslerin kullanılacağının bilinmesi gereklidir. Bu da şöyle yapılır: Durak perdesi üzerinde bulunan Rast beşlisi simetrik olarak tiz durağın üstüne göçürülür. Seyir; Durak perdesinde, dizinin durak üzerindeki seslerinden, durak altında genişlemiş kısmın seslerinden seyre başlanabilir. Karışık gezinip Nevâ perdesinde yarım karar yapılır" (Özkan, 2016: 137-139).

\section{b-) Ekrem Karadeniz}

"Giriş ve karar; Rast makamı çoğunlukla Rast veya ona yakın bir perdeden terennüme başlar. Birçok bestekârlar bu makama Rast'tan başka Segâh veya Nevâ perdesinden de girmişlerdir. Iskala: Bu makam çıkışta ve inişte iki ayrı ıskala kullanır. $\mathrm{Bu}$ iki ıskala arasındaki fark, çıkışta kullanılan Eviç perdesinin yerine inişte Acem 
perdesinin kullanılmasından ibarettir. Seyir ve çeşni; Rast makamı Rast veya uygun diğer bir perdeden terennüme başlayıp önce Nevâ perdesine kadar olan sahada dolaşır. Seyir sırasında Nevâ perdesi üzerinde de kısa duruşlar yapar. Bir kısım musikî erbabı karardan önce Arak perdesini de göstermişler ve buradan Yegâh perdesine kadar indikten sonra tekrar Rast perdesine gelip burada karar vermişlerdir" (1965: 85-86).

\section{c-) Yakup Fikret Kutluğ}

"Rast makamı, çıkıcı bir nitelik gösterir. Eski bestekârlarımız, genelde Rastta karar perdesi olan Rasttan seyre başlamışlar, seyri tize doğru yöneltmişler ve ilk dörtlü içinde çeşniyi göstermişlerdir. Rast perdesi etrafında yapılan ilk seyirlerde, aynı zamanda Yegâh'a doğru bir pestleşme görülürse de bu iniş Yegâh perdesine kadar devam etmez, Hüseyni Aşiran perdesi hem asma karar hem de vurgulama perdesi olarak gösterilir ve Rasta doğru dönüş yapılır. Eğer Yegâh perdesi sıkça gösterilirse, bu sefer Rehavi makamına bir geçiş olur ki, bu tür bir geçkiyi bestekârlarımız uygun bulmamışlar ve buna dikkat etmişlerdir. Yine Rast perdesi etrafındaki seyirler sırasınada, Segâh perdesi en önemli asma karar perdesi görevini yüklenmiştir. Segâh perdesinde, Segâh makamına geçilerek asma kararlar verildiği gibi, sırf Segâh perdesi, asma karar perdesi olarak, özellikle kullanılır ve Segâh makamı dışında bir seyir ile asma kararlar verilir, vurgulamalar yapılır. Çargâh perdesi, Rast dörtlüsünün tiz perdesidir. Bu perde üzerinde de vurgulamalar, hatta asma kararlar verildiği görülür. Gerdaniye tiz durak perdesidir. Makam tiz durak etrafındaki seslerde seyirler gösterirken Nevâ ile Gerdaniye arasındaki Rast dörtlüsü içinde, Rast çeşnisini gösterdiği gibi, Gerdaniyeden tize doğru çıkışlarda, yine Rast seyirlerini oluşturduğunu görürüz. $\mathrm{Bu}$ arada, miyan açışlarda, Gerdaniyeden itibaren başka yakın makamlara geçkiler yapılması usuldendir. Mesela, Tiz Segâh'ta Segâh, Muhayyer veya Tahir Sünbüle açılmak suretiyle Gerdaniye'de Nihavend gibi. Nevâ perdesinin güçlü olarak icrası sırasında, bestekâr veya icracının başka makamlara geçmek istemesi tabii bir olaydır. Daha başka geçkilerin yapılması da her zaman mümkün ve isteğe bağlıdır" (2000: 163164).

Rast makamında bestelenmiş olan, tezin tahlil basamağı kısmında yer alan on (10) örnek esere bakıldığında; dokuz (9) eserin Rast ve bir (1) eserin de Nevâ perdesini merkez alarak seyre başladıkları görülmüştür. Buna göre; Rast makamının hangi perdeyi merkez alarak seyre başlayacağına özgü olarak tarfilere bakıldığında 19. yy. nazariyat eserlerinden Abdülbâki Nasır Dede ve Tanburi Cemil Bey'in eserlerinde bulunan tarfiler ile örtüşmektedir. 20. yy. nazariyat yaklaşımları bakımından Hüseyin Sadettin Arel, Ekrem Karadeniz ve Yakup Fikret Kutluğ'un tarifleri ile de örtüşmektedir. Dolayısıyla mevcut tariflere bakıldığında Rast makamının hangi perdeyi merkez alarak seyre başlayacağına özgü olarak yüzyıllar arasında bir farklılık görülmemiştir.

Rast makamının genişlemesi olarak incelenen on (10) eserin sekizinde (8) Yegâh, birinde (1) Kaba Nim Hicaz ve bir (1) eserde Hüseyniaşiran en pest ses olarak kullanılmıştır. Tiz taraftan genişlemede ise; iki (2) eserde Tiz Hüseyni, iki (2) eserde Tiz Nevâ, iki (2) eserde Tiz Çargâh, iki (2) eserde Tiz Segâh ve iki (2) eserde Muhayyer perdeleri en tiz perde olarak kullanılmıştır. Bu bağlamda 19. yy. nazariyat eserlerinden Abdülbâki Nasır Dede'nin eserinde, kullanılacak en pest perdenin Yegâh perdesi olacağı hususundaki ifadesi örtüşürken, en tiz perdenin Gerdaniye perdesi olacağını tarif etmesiyle tiz taraftan genişleme konusunda yapmış olduğumuz tahliller ile örtüşmemektedir. Tanburi Cemil Bey, Yegâh ve Tiz Nevâ perdelerini işaret etmiş ve böylelikle eserlerde Rast makamının genişleme özelliği ile mevcut tarifin örtüştüğü görülmektedir. 20. yу. nazariyat yaklaşımları bakımından Hüseyin Sadettin Arel yaklaşımındaki pest taraftaki genişleme tarifi ile örtüşürken, makamın ağır başlı bir makam olduğundan ve tiz taraftan çok seyrek genişlediğinden bahsediyor. Tahlillere baktığımızda Hüseyin Sadettin Arel'in Rast makamının tiz taraftan genişleme hususundaki tarifi örtüşmemektedir. Ekrem Karadeniz yaklaşımında en pest ses Yegâh olabileceğinden bahsediyor (ki bu eserlerdeki tespit ile örtüşmektedir) fakat tiz taraftaki 
genişleme bahsinde bir ifade yer almamaktadır. Yakup Fikret Kutluğ'un Rast makamının genişleme konusunda yapmış olduğu tarifi ile de kısmen örtüşmektedir.

Rast makamındaki tahlil edilen on (10) eserin 1. hanelerinde en çok kullanılan geçki/çeşni Yegâh'da Rast, yerinde Uşşak ve yerinde Segâh'dır. Mülazime bölümlerinde en çok kullanılan geçki/çeşni yerinde Segâh ve Yegâh'da Rast'dır. 2. hanelerinde en çok kullanılan geçki/çeşniler yerinde Uşşak ve Yegâh'da Rast'dır. 3. hanelerinde en çok kullanılan geçki/çeşni yerinde Segâh ve yerinde Uş̧̧ak'dır. 4. hanelerinde en çok kullanılan geçki/çeşni yerinde Nikriz ve yerinde Hicaz'dır. 19. yy. edvar ve nazariyat eserlerinde Rast makamı tariflerinde geçki/çeşni özelliğine dair herhangi bir bilgi bulunmamaktadır. Bu bağlamda eserlerde tespit edilen özellikler ile 20. yy. nazariyat yaklaşımları bakımından Hüseyin Sadettin Arel ve Yakup Fikret Kutluğ'un Rast makamı tarifinde kullanmış oldukları geçki/çeşni özellikleri ile benzerlik göstermektedir. Ekrem Karadeniz'in Rast makamı tarifinde ise geçki/çeşni özelliğine dair bir ifade yer almamaktadır.

Rast makamına yönelik tahlil edilen peşrevler sonucu elde edilen bulgular ile 19 ve 20 . yy ait Rast makamının tariflerine bakıldığında, Rast perdesini merkez alarak seyre başladığı görülmektedir. Rast makamının genişleme bakımından eserlerde ve tarfilerde çoğunlukla en pest ses Yegâh, en tiz ses ise Tiz Nevâ perdeleri arasındaki ses sahasını kullandığı görülmektedir. Rast makamı içerisinde kullanılan geçki/çeşni özelliğine bakıldığında 19. yy edvar ve nazariyat eserlerinde herhangi bir geçki/çeşni kullanım ifadesine yer verilmediği görülmüş, 20. yy nazariyat yaklaşımlarından Hüseyin Saddettin Arel'in tarifinde bulunan ifadeler ile örtüştügü görülmektedir. Genel olarak Rast makamında en çok kullanılan geçki/çeşni kullanımının Yegâh'da Rast olduğu görülmüştür. Rast makamına ait peşrevlerin tahlili sonucu elde edilen bulgulardaki geçki/çeşni kullanımlarının birçoğunun Rast makamına yönelik yapılmış olan tariflerde yer almadığı görülmüştür.

\subsection{Nazariyat Eserlerindeki Uşşak Makamına Yönelik Tarifler}

\subsubsection{9. yy Nazariyat Eserlerindeki Uşşak Makamı Tarifleri}

\section{a-) Abdülbâki Nasır Dede}

"Nevâ perdesinden başlayarak Çargâh, Segâh ve Dügâh perdesine iner ve orada karar verir. Ancak Nevâ perdesinden yukarı Hüseyni, Acem, Gerdaniye ve Muhayyer perdesine kadar yükselir. Bu makamın asıl sonraki eskilerin (Kudemâ-i müteahhirin) Nevâ dediği makam ve eskilerin (Kudemâ) Nevrûz-1 asl dediği avazedir. Daire konusundaki anlaşmazlık bu makamda da söz konusudur” (Başer, 2013: 127).

\section{b-) Haşim Bey}

"Önce Rast, Dügâh, Segâh, Çargâh, Nevâ, Hüseyni perdeleriyle başlanılarak Rasta kadar inip, sonrasında Gerdaniye, Acem, Hüseyni, Nevâ, Çargâh, Segâh, Dügâh, Rast açarak Dügâh'ta son bulur. Ancak bu makamda Nevâ'dan yukarısı Beyati ve aşağısı Uzzal perdesiyle başlanır ise de Dügâh makamına benzerliği sebebiyle, ben bu makama ne Beyati ve ne Dügâh diyebiliyorum. Benzer olması sebebiyle Dügâh makamına fazlasıyla eğilimli olması sebebiyle Dügâh olarak da adlandırılabilir. Ve bu makam alafranga'da her ne kadar la kalırsa da yine sol notaya benzerliği sebebiyle sol ton denir" (Tirışkan, 2000: 24-25).

\section{c-) Tanburi Cemil Bey}

"Uşşak makamının zemini; medhalde Rast, Dügâh perdeleriyle Gerdaniye, Rast veyahud Gerdaniye-Yegâh fasılasında miyanı; Eviç perdesi ile Nevâ-Tiz Nevâ oktavında kararı dahi; Muhayyer ile Rast perdeleri arasındadır" (Cevher, 1992: 47). 


\title{
3.4.2. 20. yy Nazariyat Eserlerindeki Uşşak Makamı Tarifleri
}

\section{a-) Hüseyin Sadettin Arel}

\begin{abstract}
"Durağı; Dügâh perdesidir. Seyri; Çıkıcıdır. Dizisi; Yerinde Uşşak dörtlüsüne Nevâ'da Buselik beşlisinin eklenmesinden meydana gelmiştir. Güçlüsü; Nevâ perdesidir. Asma karar perdeleri; Segâh perdesi üzerinde Segâh ve Ferahnak, Rast perdesinde Rast asma kararları yapılır. Genişlemesi; Uşşak makamı çıkıcı, ağırbaşlı ve dînî duygular uyandıran bir makamdır. $\mathrm{Bu}$ yüzden makamın ağırbaşlılığının bozulmaması için genişlemesi, daima dizinin pest tarafından durak altından yapılır. Bu da Yegâh perdesinde bir Rast beşlisi oluşturmakla elde edilir. Bu makam tiz durak üstünde hemen hiç dolaşmaz. Tiz taraftan bir genişleme -tamamen teorik de olsa- söz konusudur. Tiz taraftan düşünülen genişleme iki şekilde olabilir: 1- Yerinde Uşşak dörtlüsü simetrik olarak tiz durağın üstüne göçürülebilir. 2-Güçlü Nevâ perdesi üzerindeki Buselik beşlisi Muhayyer perdesinde Kürdi dörtlüsü eklenmesiyle, Nevâ’da Buselik dizisi halinde uzatılabilir. Seyir; Durak civarından, durağın altından genişlemiş bölgenin seslerinden seyre başlanır" (Özkan, 2016: 143-145).
\end{abstract}

\section{b-) Ekrem Karadeniz}

"Giriş ve karar; Çoğunlukla Rast ve Dügâh perdesinden terennüme başlar. Ancak ıskalanın öbür uygun perdelerinden de terennüme başaldığı olur. Dügâh perdesnde karar verir. Iskala; Bu makam çıkış ve inişte iki ayrı 1skala kullanır. Nota yazılırken eserin baş tarafına Eviç perdesine olan mahsus olan diyez işaretini koymak en uygun şekil olmakla beraber, inişte Eviç perdesi yerine Acem perdesi kullandığı için birçok eserin baş tarafina hiçbir işaret konulmadığı ve arızaların yeri geldikçe nota arasına yazıldığı görülmüştür. Uşşak perdesine mahsus bir komalık bemol işaretinin yazıldığı da görülmemiştir. Saz sanatkârları bu perdeyi kulaklarıyla duyar ve çalarlar. Seyir ve çeşni; Rast, Dügâh bazen de Çargâh, Nevâ perdelerinden terennüme başlayıp 1skaladaki perdelerle seyrederek Nevâ perdesi üzerinde kısa duruşlar yapar ve inişte Eviç ve yerine Acem, Segâh yerine de Uşşak perdesi kullanarak Dügâh perdesinde karar verir. Karar esnasinda bazen Rast perdesi kullanıldğı ve pest tarafta Yegâh perdesine kadar inildiği de olur" (1965: 93-94).

\section{c-) Yakup Fikret Kutluğ}

"Uşşak makamı çıkıcı bir nitelik gösterir. Makam yeden perdesi olan Rast perdesini göstererek Dügâh açar. İlk seyirlerin Dügâh perdesi etrafındaki seslerde yapıldığı görülür. Bu seyirler sırasında, Rast perdesinde vurgulamalar ve kısa asma kararlar verilir. Yine bu seyir sırasında, Yegâh perdesine doğru, Rast çeşnisi ile pestleşme durumu, makamın kuruluşunda bulunmayan bir ilave ve genişleme olarak yapılır. Bestekârlarımız, Yegâh'a düsserek, Yegâh üzerinde Rast göstermeyi adeta bir gelenek durumuna getirmişlerdir. Dügâh'tan tize doğru, Uşşak dörtlüsü içinde gösterilen seyirlerde, Nevâ perdesi sıkça gösterilir ve Dügâh'a doğru pestleşirken Segâh perdesi üzerinde sıkça vurgulamalar ve özellikle asma kararlar verildiği görülür. Nevâ perdesi üzerinde yapılan seyirler, Buselik beşlisi içinde olmasına rağmen, Buselik'in özelliklerini göstermez. Gerdaniye gösterilerek Nevâ'ya düşüşler yapılır. Nevâ perdesi güçlü perdesidir. En çok asma karar verilen perdedir. Bu kararlarda, Nim Hicaz perdesi yeden olarak alınmaz. Çargâh perdesi kullanılır. Nevâ üzerinde Hicaz ve Çargâh perdesi üzerinde Nikriz geçkileri, Uş̧̧ak'ta çok az kullanılan, öenmsiz geçkilerdir. Muhayyer perdesi tiz duraktır. Eserine miyan açmak isten bestekâr veya icracının, Muhayyer'den itibaren, kendi doğuşuna bağlı bir makamdan miyan açabileceği gibi, çoğu zaman Muhayyer makamına geçki yaparak miyan açtığı da görülür" (2000: 168-169).

Uşşak makamında bestelenmiş olan, tezin tahlil basamağı kısmında yer alan on (10) örnek esere bakıldığında; yedi (7) eserin Dügâh, iki (2) Rast ve eserin bir (1) eserin de Nevâ perdesini merkez alarak seyre başladıkları görülmüştür. Buna göre; Uşşak makamının hangi perdeyi merkez alarak seyre başlayacağına özgü olarak tariflere bakıldığında 19. yy. edvar ve nazariyat eserlerinden Abdülbâki Nasır Dede, Nevâ perdesini işaret ederken, Haşim Bey ve Tanburi Cemil 
Bey ise Dügâh perdesini işaret etmişler ve tespit edilen bulgular ile çoğunlukla örtüşmektedir. 20 . yy. nazariyat yaklaşımları bakımından Hüseyin Sadettin Arel, Ekrem Karadeniz ve Yakup Fikret Kutluğ'un tarifleri ile örtüşmektedir. Dolayısıyla mevcut tariflere bakıldığında Uşşak makamının hangi perdeyi merkez alarak seyre başlayacağına özgü olarak yüzyıllar arasında bir farklılık ortaya konulmuştur.

Uş̧̧ak makamının genişlemesi olarak incelenen on (10) eserin tamamında Yegâh perdesi en pest ses olarak kullanılmıştır. Tiz taraftan genişlemede ise; sekiz (3) eserde Tiz Nevâ ve birer (1) eserde Tiz Hüseyni, Sünbüle perdeleri en tiz perde olarak kullanılmıştır. Bu bağlamda 19. yy. nazariyat eserlerinden Abdülbâki Nasır Dede'nin eserinde makamın tiz taraftan Muhayyer perdesine kadar yükselebileceği ifadesi ile tahliller örtüşmemektedir. Haşim Bey'in edvarında genişleme bahsine dair bir ifade yer almamaktadır. Tanburi Cemil Bey, Yegâh ve Tiz Nevâ perdelerini işaret etmiş ve böylelikle eserlerde Uşşak makamının genişleme özelliği ile kısmen örtüştüğü görülmektedir. 20. yy. nazariyat yaklaşımları bakımından Hüseyin Sadettin Arel, Uşşak makamının tarifinde pest taraftaki genişlemede Yegâh perdesini işaret etmiş (ki bu tarif eserlerin tahlili ile örtüşmektedir), tiz taraftan ise hemen hiç genişlemeyeceği ifadesine yer vermiştir. Ekrem Karadeniz yaklaşımında pes tarafran genişleme hususunda Yegâh perdesini işaret ediyor, fakat tiz taraftaki genişleme bahsinde bir ifade yer almamaktadır. Yakup Fikret Kutluğ'un Uşşak makamının genişleme konusunda yapmış olduğu tarifi ile de bire bir örtüşmektedir.

Uşşak makamındaki tahlil edilen on (10) eserin 1. hanelerinde en çok kullanılan geçki/çeşni yerinde Rast ve Yegâh'da Rast'dır. Mülazime bölümlerinde en çok kullanılan geçki/çeşni yerinde Rast'dır. 2. hanelerinde en çok kullanılan geçki/çeşniler yerinde Rast ve Hüseyni'de Uşşak'tır. 3. hanelerinde en çok kullanılan geçki/çeşni yerinde Rast, Nevâ perdesinde Rast ve Gerdaniye'de Buselik'dir. 4. hanelerinde en çok kullanılan geçki/çeşni yerinde Rast ve yerinde Segâh'tır. 19. yy. edvar ve nazariyat eserlerinde Uşşak makamı tariflerinde geçki/çeşni özelliğine dair herhangi bir bilgi bulunmamaktadır. Bu bağlamda eserlerde tespit edilen özellikler ile 20. yy. nazariyatlarından Hüseyin Sadettin Arel ve Yakup Fikret Kutluğ’un Uşşak makamı tarifinde kullanmış oldukları geçki/çeşni özellikleri ile benzerlik göstermektedir. Ekrem Karadeniz' in Uşşak makamı tarifinde ise geçki/çeşni özelliğine dair bir ifade yer almamaktadır.

Uşşak makamına yönelik tahlil edilen peşrevler sonucu elde edilen bulgular ile 19 ve 20 . yy ait Uşşak makamının tariflerine bakıldığında, Dügâh perdesini merkez alarak seyre başladığı görülmektedir. Uşşak makamının genişleme bakımından eserlerde ve tarfilerde çoğunlukla en pest ses Yegâh, en tiz ses ise Tiz Nevâ perdeleri arasındaki ses sahasını kullandığı görülmektedir. Uşşak makamı içerisinde kullanılan geçki/çeşni özelliğine bakıldığında 19. yy edvar ve nazariyat eserlerinde herhangi bir geçki/çeşni kullanım ifadesine yer verilmediği görülmüş, 20. yy nazariyat yaklaşımlarından Hüseyin Saddettin Arel ve Yakup Fikret Kutluğ'un tarifinde bulunan ifadeler ile örtüştüğü görülmektedir. Genel olarak Uşşak makamında en çok kullanılan geçki/çeşni kullanımının yerinde Rast olduğu görülmüştür. Uşşak makamına ait peşrevlerin tahlili sonucu elde edilen bulgulardaki geçki/çeşni kullanımlarının birçoğunun Uşşak makamına yönelik yapılmış olan tariflerde yer almadığı görülmüştür.

\subsection{Rast Makamına Yönelik Geçki/Çeşni Etütleri}

Rast makamına yönelik tahlil edilen peşrevler doğrultusunda haneler içerisinde en çok kullanılan geçki/çeşniler;

1. hane içerisinde; Yegâh'da Rast (16 adet), Yerinde Uşşak (7 adet),

Mülazime içerisinde; Yerinde Segâh (3 adet), Yegâh'da Rast (3 adet),

2. hane içerisinde; Yerinde Uşşak (8 adet), Yegâh'da Rast (6 adet),

3. hane içerisinde; Yerinde Segâh (5 adet), Yerinde Uşşak (5 adet),

4. hane içerisinde; Yerinde Nikriz (5 adet), Yerinde Hicaz (4 adet) şeklindedir.

www.turkishstudies.net/turkishstudies 
3.5.1. Rast Etüt - 1

\section{RAST ETÜT - 1}

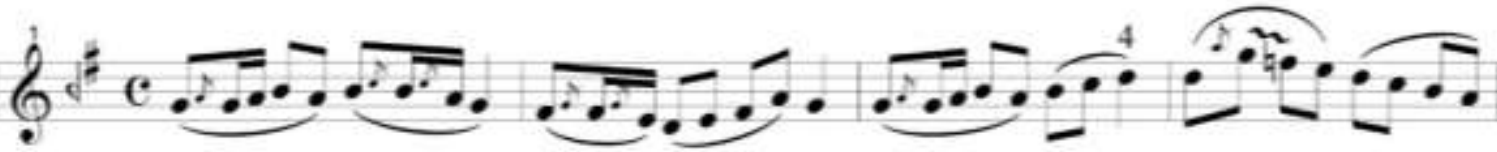

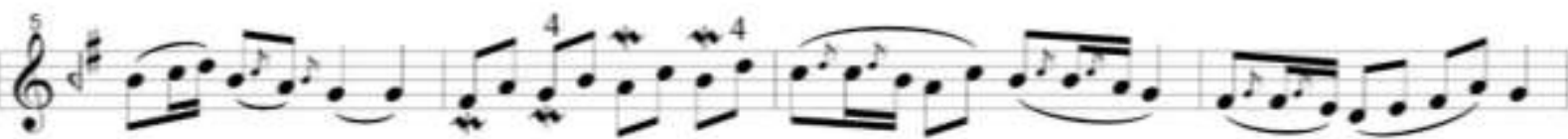

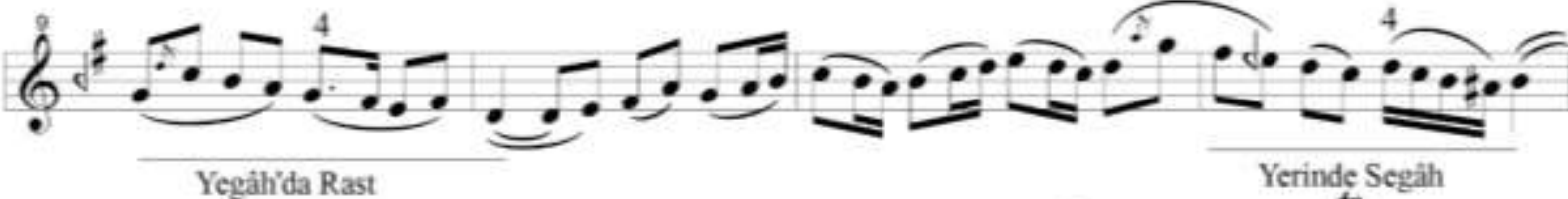

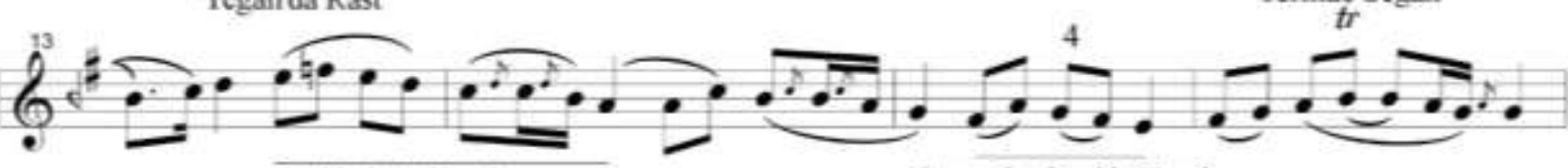
Yerinde Ușşak Hüseyni aşiran'da Uş̧sak

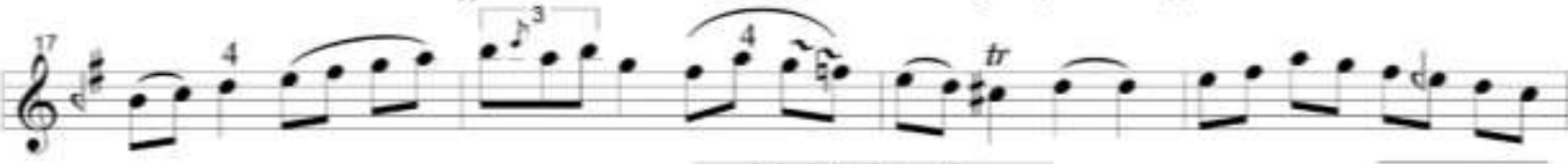

Nevă'da Buselik

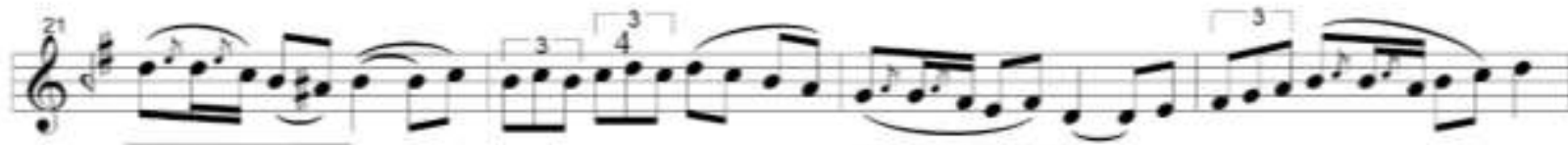
Yerinde Segath Yegåh'da Rast

6 $6_{\text {Yerinde Hürram }}^{6}$ $\frac{6}{\text { Nevi'da Buselik }}$ $6^{2}$ Hetseyni aşiran'da Karcığar 


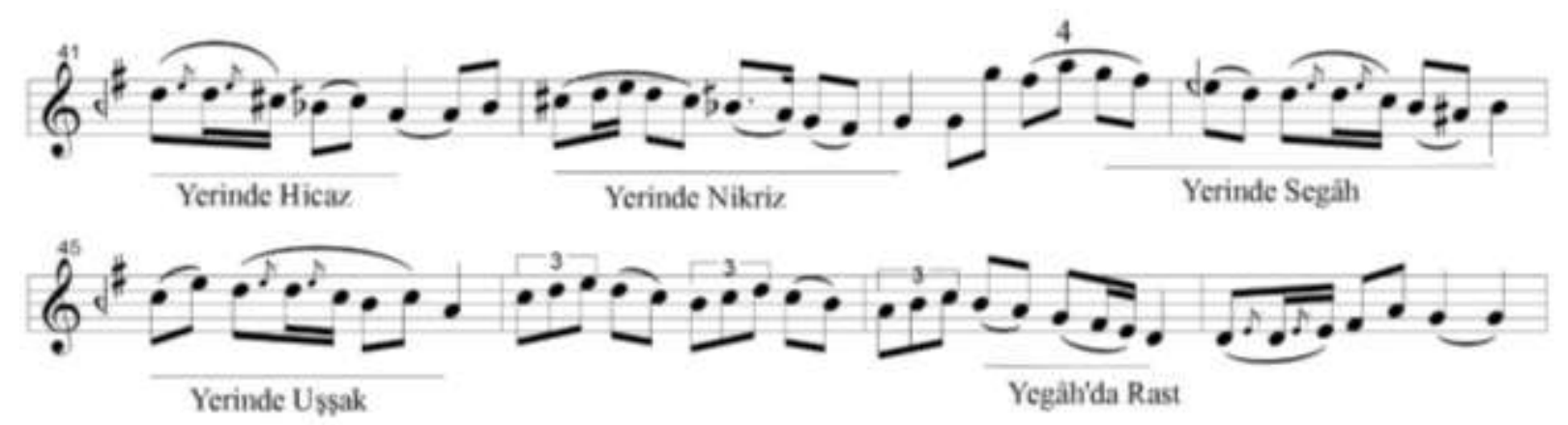

Rast makamındaki birinci etüt, geçki/çeşnilerin daha iyi anlaşılması amacıyla, temel tartım kalıpları dikkate alınarak oluşturulmuştur. Rast perdesi merkez alınarak seyre başlanmış ve etüdün bütününde Yegâh ile Tiz Segâh perdeleri arasındaki ses sahası/alanı kullanılmıştır. Gider (tempo) 70-80 bpm (dörtlük nota değeri) olarak belirlenmiştir. Etüt içerisinde Legato ve Detache yay teknikleri ile Çarpma, Mordan, Glissando ve Tril süsleme tekniklerine yer verilmiştir. Buna göre;

- Etüt icrasına başlamadan önce Rast makamı içerisindeki en sık kullanılan geçki/çeşnilerin bulunduğu ölçüleri alıştırma olarak çalışınız.

- Etüdü belirlenen giderde (tempoda) öncelikle sadece etütde yer alan yay teknikleri ile, yeterli gelişim gösterdikten sonra kullanılan süsleme tekniklerini dikkate alarak icra ediniz.

- Dördüncü parmak ve boş tel kullanımına yönelik etüt içerisinde belirtilen parmak numaralarına göre icra etmeye,

- Süsleme tekniklerini kullanarak icra ederken notaların süre değerlerini aşmamaya,

- Glissando süsleme icrasının yoğun olmamasına dikkat ediniz.

- Üçlemeler içerisinde yer alan Çarpma tekniği için yazılan notaların icrasında esas notaların değerini aşmamaya,

- Yerinde Uşşak geçki/çeşni kullanımı bulunan ölçüler içerisindeki Segâh perdesinin icrasına dikkat ediniz. 
3.5.2. Rast Etüt - 2

\section{RAST ETÜT - 2}

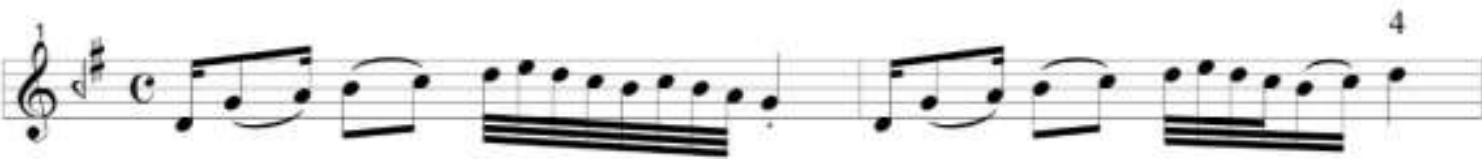

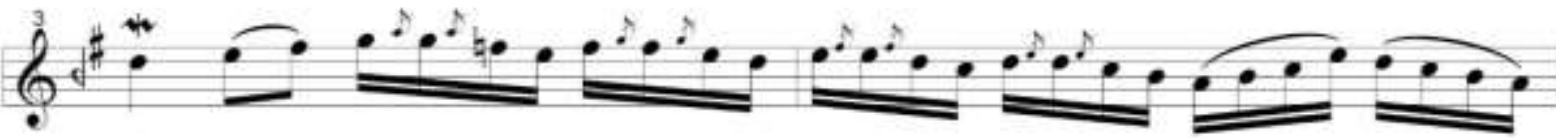
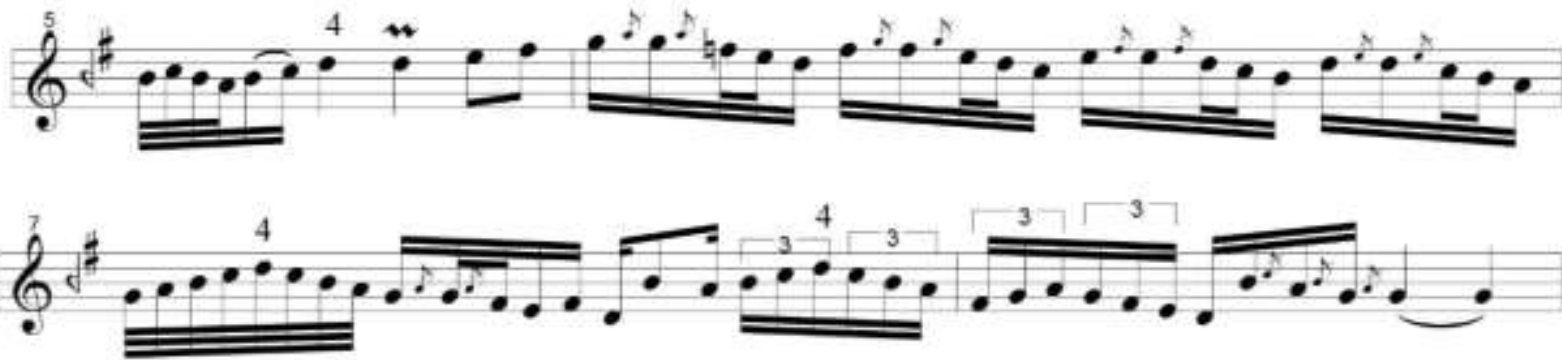

$e^{f \prime \prime 200}$

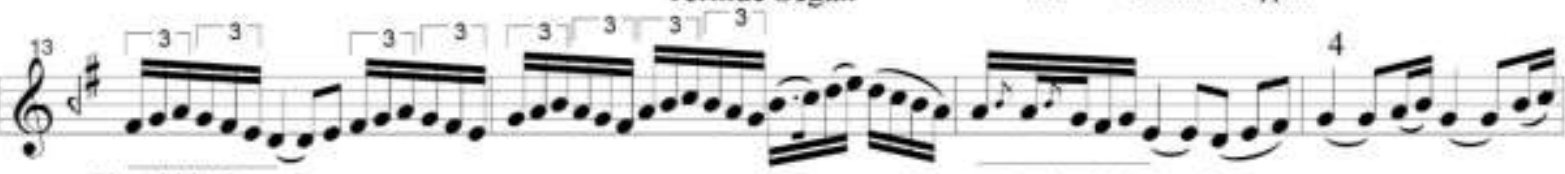
Yegâh'da Rast

Hüscyni aşiran'da Ușșak

$6^{4}$ Nevâ'da Busclik

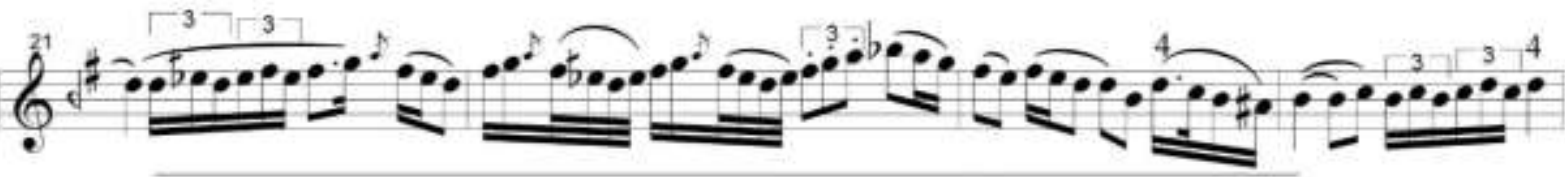
$Q^{2}=-\cdots \cdots$ Yerinde Suzinak

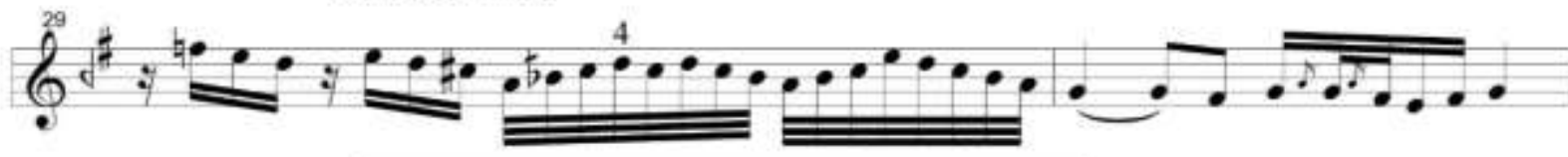
Yerinde Nikriz 


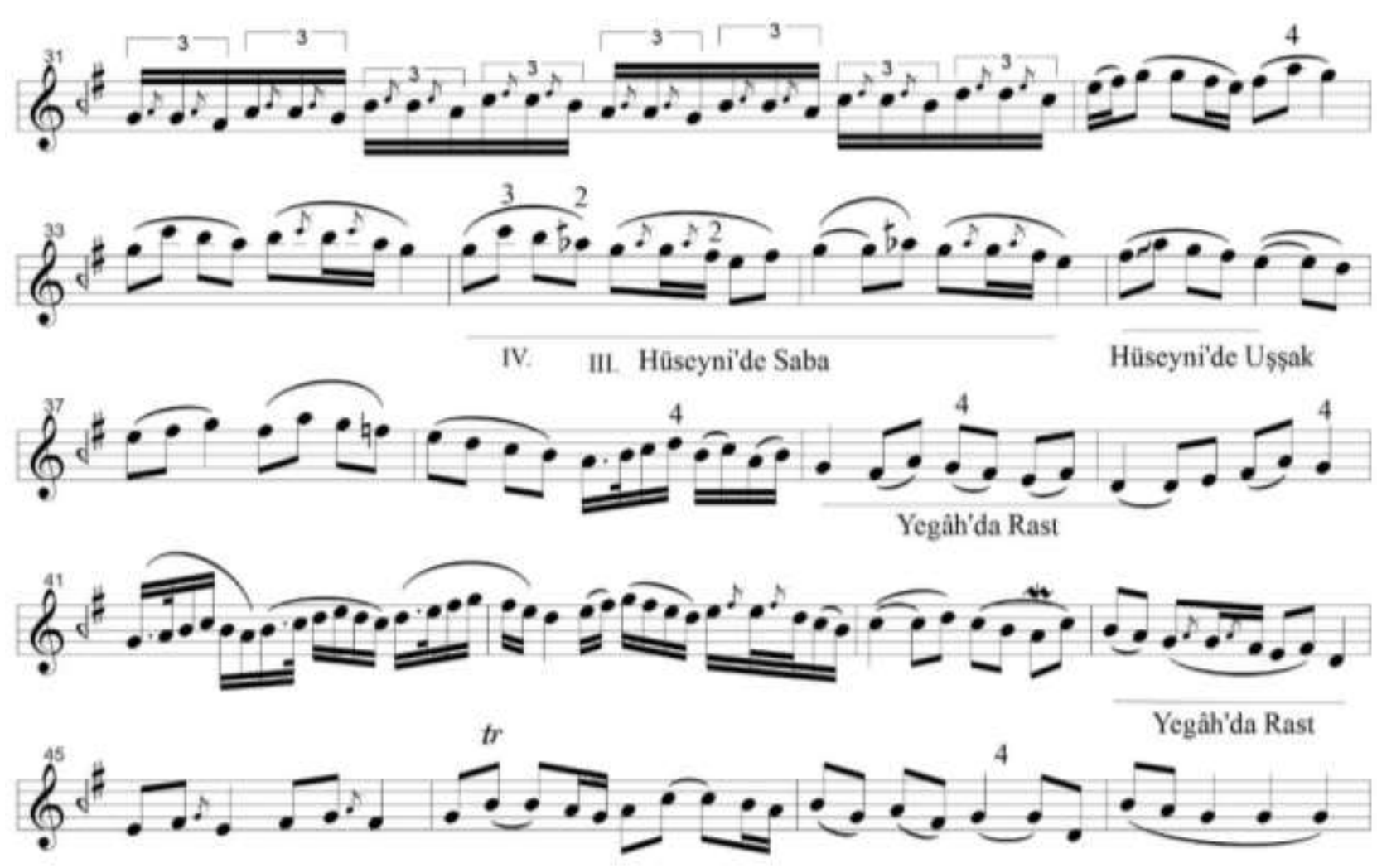

Rast makamındaki ikinci etüt, farklı tartım kalıpları dikkate alınarak oluşturulmuştur. Rast perdesi merkez alınarak seyre başlanmış ve etüdün bütününde Yegâh ile Tiz Çargâh perdeleri arasındaki ses sahası/alanı kullanılmıştır. Gider (tempo) 140-150 bpm (sekizlik nota değeri) olarak belirlenmiştir. Etüt içerisinde Legato, Detache ve Staccato yay teknikleri ile Çarpma, Mordan, Glissando ve Tril süsleme tekniklerine yer verilmiştir. Buna göre;

- Etüt icrasına başlamadan önce Rast makamı içerisindeki en sık kullanılan geçki/çeşnilerin bulunduğu ölçüleri alıştırma olarak çalışınız.

- Etüdü öncelikle belirlenen giderde (tempoda) sadece etütde yer alan yay teknikleri ile, ardından süsleme tekniklerini ve daha sonra konum değişikliklerini dikkate alarak icra ediniz.

- Belirtilen (III. ve IV.) konum değişikliklerine,

- Konum değişikliklerinde Glissando tekniğini yoğun kullanmamaya,

- Belirtilen yay bağlarına,

- Detache yay tekniği ile icra edilmesi gereken otuz ikilik değerdeki notaların icrasında yayın orta kısmında küçük bir alan içerisinde icra etmeye dikkat ediniz.

- Glissando süsleme tekniği icrasında esas notaların vurgulu icrasına,

- Üçlemeler içerisindeki Çarpma süslemelerini oluşturan notaları belirgin bir şekilde icra etmeye,

- Dördüncü parmak ve boş tel kullanımına yönelik etüt içerisinde belirtilen parmak numaralarına göre icra etmeye dikkat ediniz. 


\subsection{Uşşak Makamına Yönelik Geçki/Çeşni Etüttleri}

Uş̧̧ak makamına yönelik tahlil edilen peşrevler doğrultusunda haneler içerisinde en çok kullanılan geçki/çeşniler;

1. hane içerisinde; Yerinde Rast (14 adet), Yegâh'da Rast (7 adet),

Mülazime içerisinde; Yerinde Rast (8 adet), Yegâh'da Rast (2 adet)

2. hane içerisinde; Yerinde Rast (16 adet), Hüseyni'de Uşşak (6 adet),

3. hane içerisinde; Nevâ'da Rast (6 adet), Yerinde Rast (6 adet),

4. hane içerisinde; Yerinde Rast (12 adet), Yerinde Segâh (6 adet) şeklindedir. 


\subsubsection{Uşşak Etüit - 1}

\section{UŞŞAK ETÜT - 1}

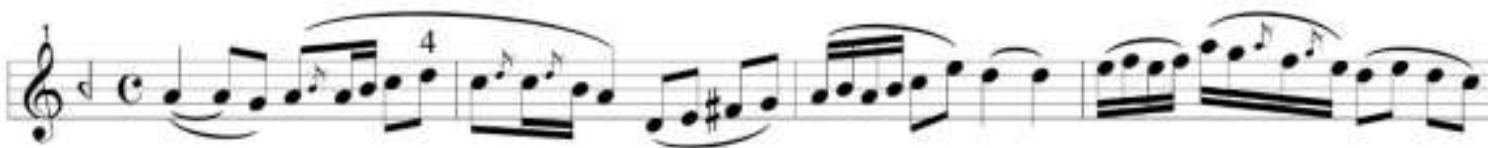
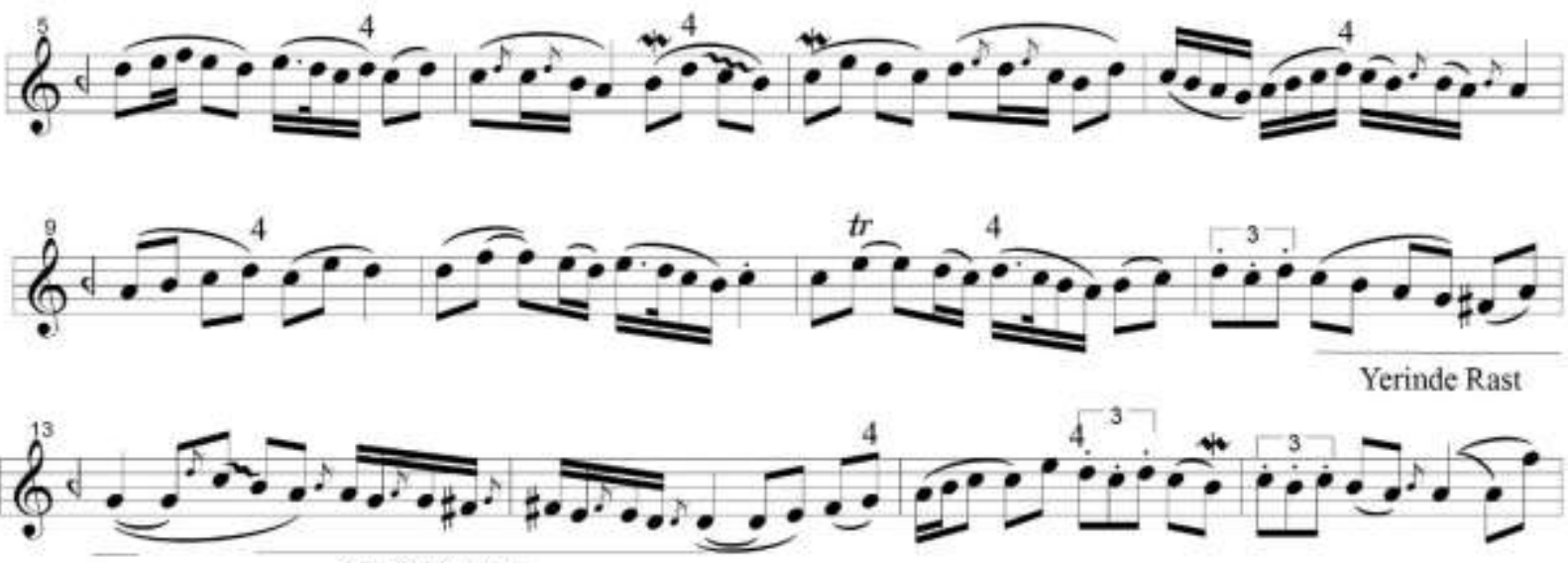
Yegâh'da Rast

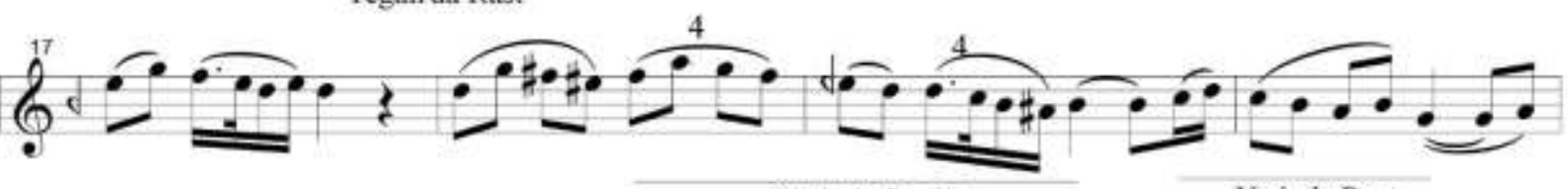
Yerinde Segãh

Yerinde Rast

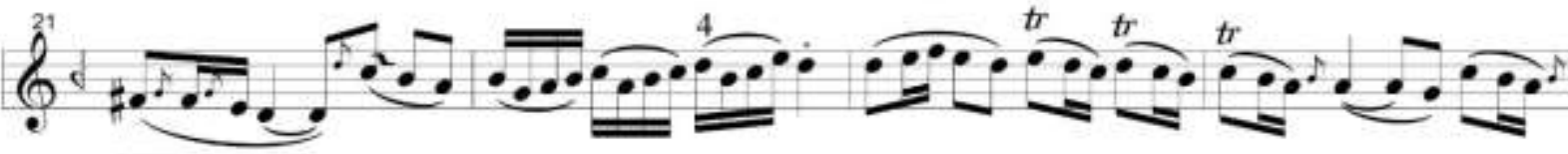
Yegåh'da Rast

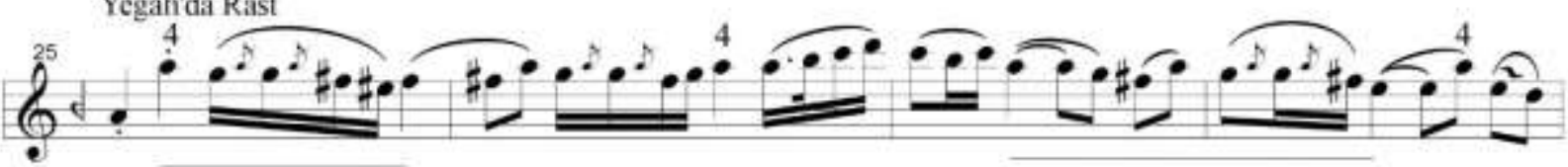
Eviç'de Eviç/Segâh

Hüseyni'de Ușşak
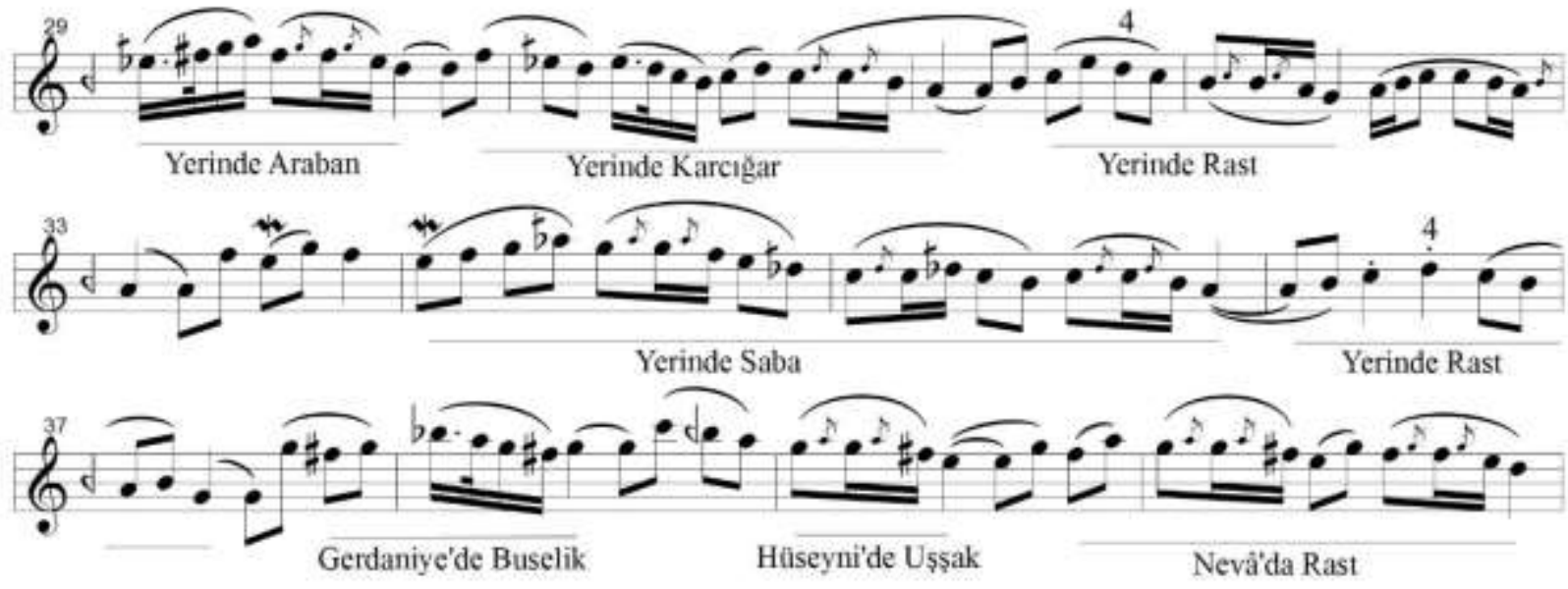


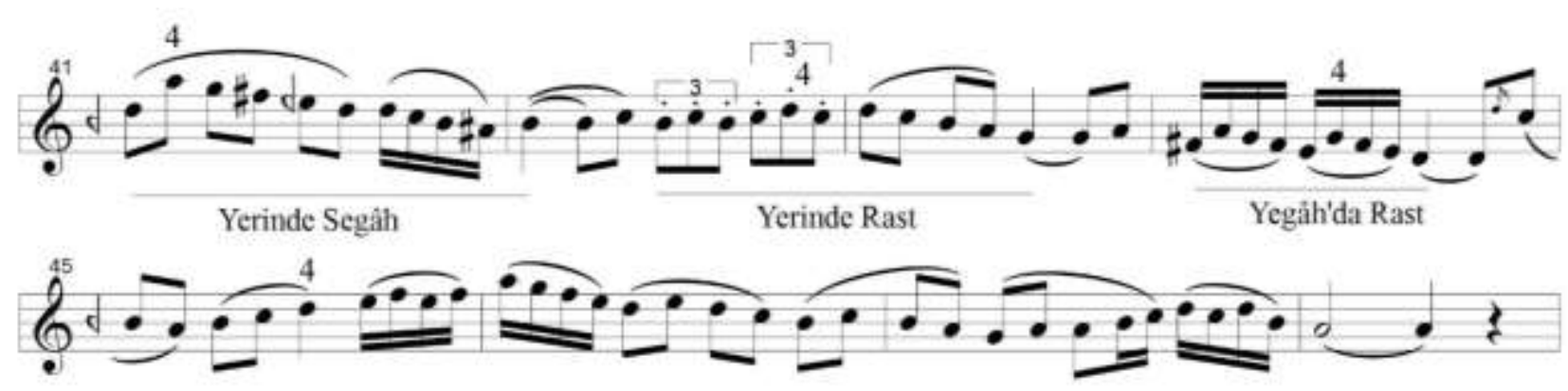

Uşşak makamındaki birinci etüt, geçki/çeşnilerin daha iyi anlaşılması amacıyla, temel tartım kalıpları dikkate alınarak oluşturulmuştur. Dügâh perdesi merkez alınarak seyre başlanmış ve etüdün bütününde Yegâh ile Tiz Nevâ perdeleri arasındaki ses sahası/alanı kullanılmıştır. Gider (tempo) 70-80 bpm (dörtlük nota değeri) olarak belirlenmiştir. Etüt içerisinde Legato, Staccato ve Detache yay teknikleri ile Çarpma, Mordan, Glissando ve Tril süsleme tekniklerine yer verilmiştir. Buna göre;

- Etüt icrasına başlamadan önce Uş̧̧ak makamı içerisindeki en sık kullanılan geçki/çeşnilerin bulunduğu ölçüleri alıştırma olarak çalışınız.

- Etüdü belirlenen giderde (tempoda) öncelikle sadece etütde yer alan yay teknikleri ile, yeterli gelişim gösterdikten sonra kullanılan süsleme tekniklerini dikkate alarak icra ediniz.

- Dördüncü parmak ve boş tel kullanımına yönelik etüt içerisinde belirtilen parmak numaralarına göre icra etmeye,

- Süsleme tekniklerini kullanarak icra ederken notaların süre değerlerini aşmamaya,

- Glissando süsleme icrasının yoğun olmamasına,

- 19 ve 41. ölçüler içerisindeki Segâh perdesinin ölçü içerisindeki geçki/çeşni kullanımı için gerekli olan baskı hassasiyetine dikkat ediniz. 


\subsubsection{Uşşak Etüt - 2}

\section{UŞŞAK ETÜT - 2}
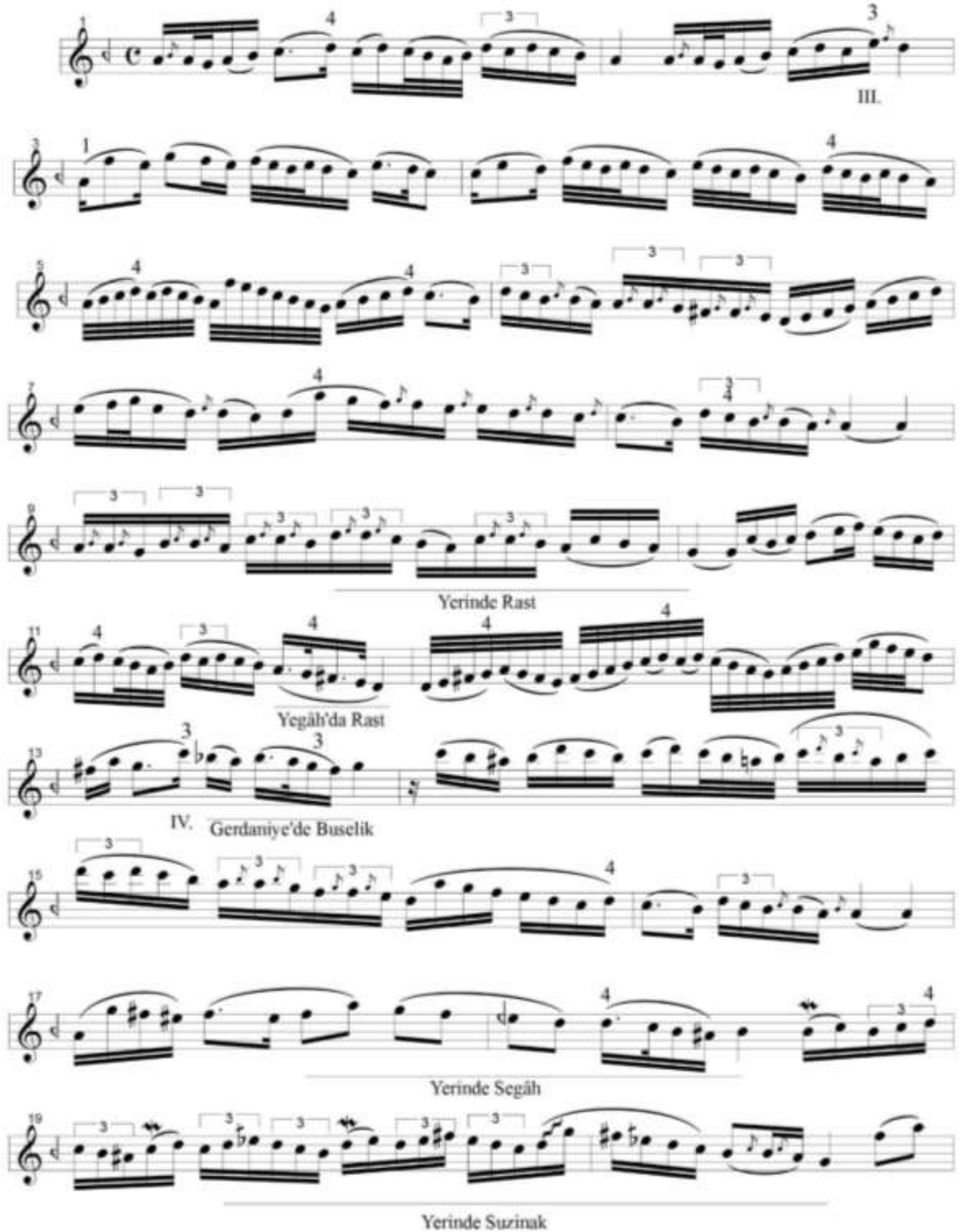

Yerinde Surinak 


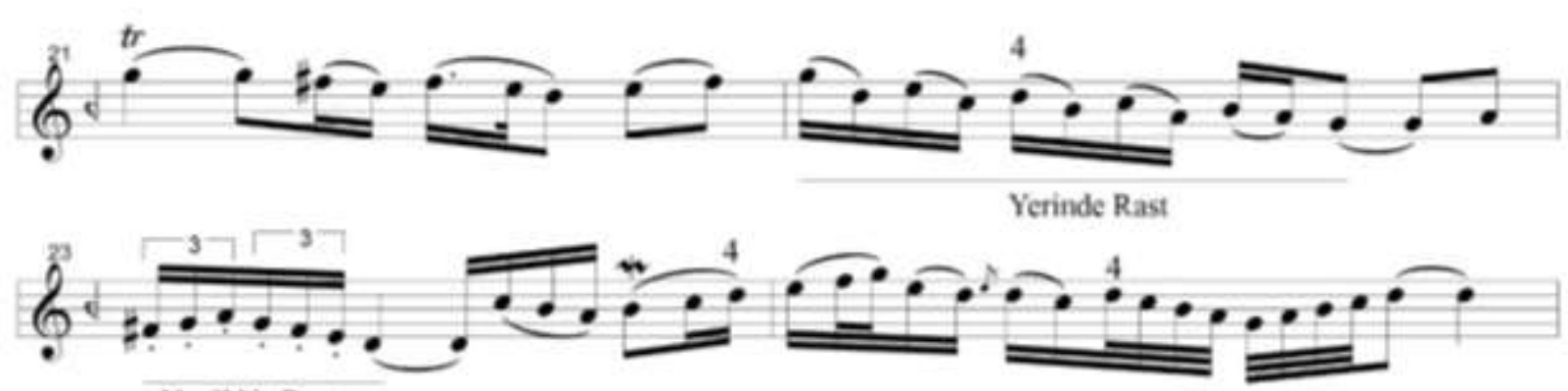

\section{Yegih'da Rast}
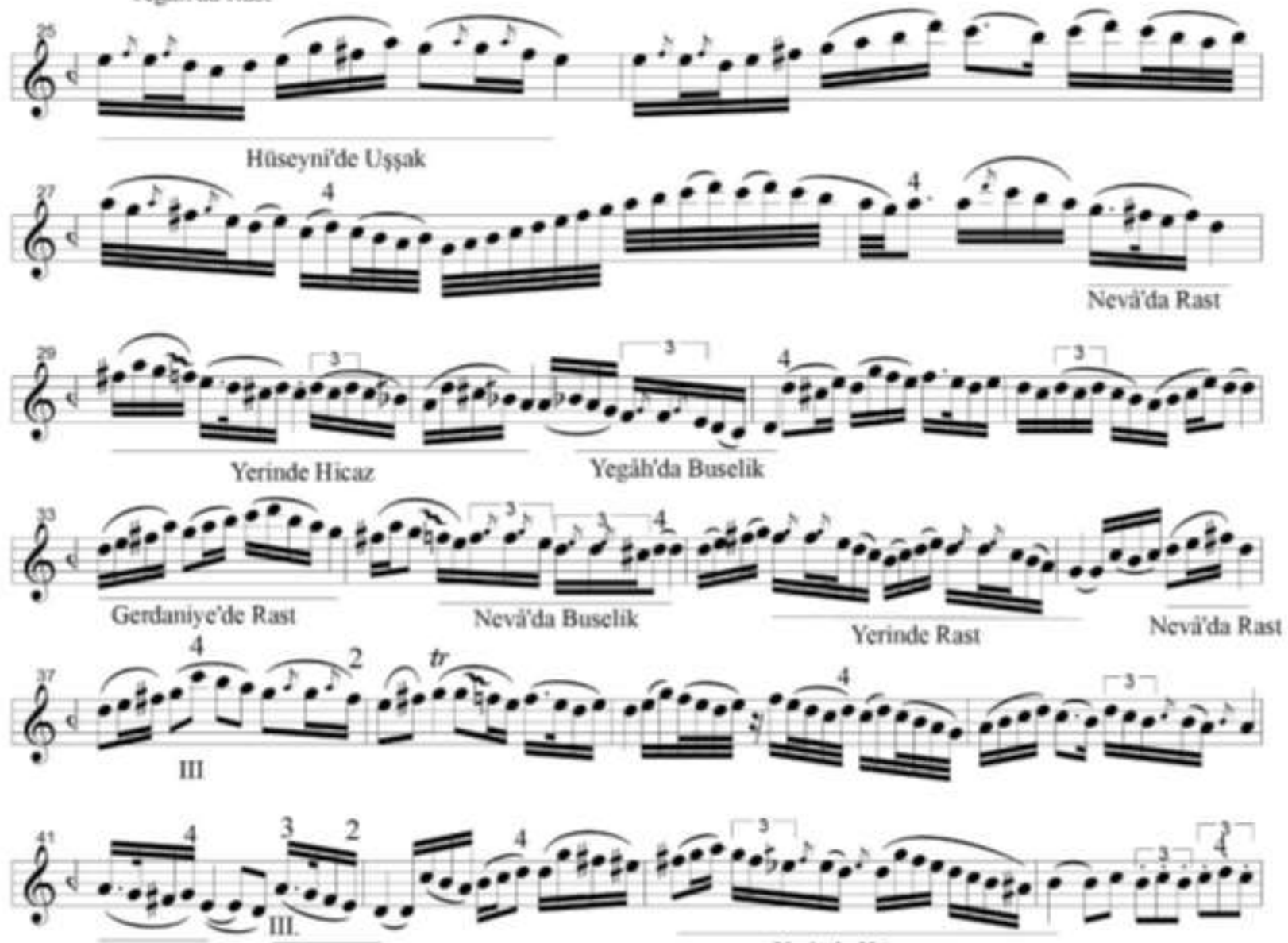

Hetseyni Așiran'da Ussak Yegâlida Rast

Yerinde Howam

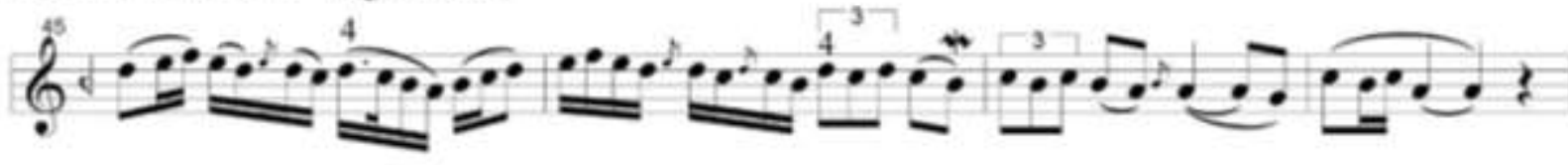

Uşşak makamındaki ikinci etüt, farklı tartım kalıpları dikkate alınarak oluşturulmuştur. Dügâh perdesi merkez alınarak seyre başlanmış ve etüdün bütününde Kaba Nim Hicaz ile Tiz Nevâ perdeleri arasındaki ses sahası/alanı kullanılmıştır. Gider (tempo) 125-135 bpm (sekizlik nota değeri) olarak belirlenmiştir. Etüt içerisinde Legato, Detache ve Staccato yay teknikleri ile Çarpma, Mordan, Glissando ve Tril süsleme tekniklerine yer verilmiştir. Buna göre;

- Etüt icrasına başlamadan önce Uşşak makamı içerisindeki en sık kullanılan geçki/çeşnilerin bulunduğu ölçüleri alıştırma olarak çalışınız. 
- Etüdü öncelikle belirlenen giderde (tempoda) sadece eüttde yer alan yay teknikleri ile, ardından süsleme tekniklerini ve daha sonra konum değişikliklerini dikkate alarak icra ediniz.

- Belirtilen (III. ve IV.) konum değişikliklerine,

- Konum değiş̧ikliklerinde Glissando tekniğini yoğun kullanmamaya,

- Belirtilen yay bağlarına,

- Üçlemeler içerisindeki Çarpma süslemelerini oluşturan notaları belirgin bir şekilde icra etmeye,

- Tril süsleme icrasında usûlden ayrılmamaya,

- Dördüncü parmak ve boş tel kullanımına yönelik etüt içerisinde belirtilen parmak numaralarına göre icra etmeye,

- 9. ölçü içerisindeki üçleme tartım kalıpları içerisinde bulunan çarpma notalarını eksiksiz bir şekilde icra etmeye,

- 14 ve 39. ölçüler içerisindeki on altılık değerdeki es sürelerini aşmamaya,

- 14. ölçü içerisindeki Tiz Segâh perdesinden Çargâh perdesine geçişte yayı tellerin üzerinden kaldırmamaya,

- 18. ölçü içerisindeki Segâh perdesinin ölçü içerisindeki geçki/çeşni kullanımı için gerekli olan baskı hassasiyetine dikkat ediniz.

- 21 ve 38. ölçüler içerisindeki dörtlük nota değerindeki Gerdaniye perdesi üzerinde bulunan Tril süsleme tekniğini bağlı olduğu sekizlik nota değerindeki Gerdaniye perdesinde kullanmamaya,

- 26. ölçü içerisindeki Tiz Segâh perdesinden Eviç perdesine ve Hüseyni perdesinden Çargâh perdesindeki yay geçişlerini kol hareketi ile sağlamaya dikkat ediniz.

\section{Sonuç}

Araştırmanın bu bölümünde Rast ve Uşşak makamlarına ait Peşrevlerin makam tahlilleri doğrultusunda Türk müziği keman eğitimi ve icrasına yönelik geçki/çeşni etütlerinin oluşturulması ile ilgili sonuçlara yer verilmiştir.

\subsection{Rast Makamına İlişskin Sonuçlar}

Rast makamına yönelik peşrev formunda bestelenmiş 90 (doksan) eserden ulaşılabilen 84 (seksen dört) eser tespit edilmiştir. En çok geçki/çeşni kullanımı bakımından örneklem grubunda yer alan bu 10 (on) eserden Edhem Efendi'nin eserinde 27 (yirmi yedi), Muzaffer'in eserinde 23 (yirmi üç), Tatyos Efendi'nin eserinde 22 (yirmi iki), Sırrı Abdülbaki Dede'nin eserinde 21 (yirmi bir), Mehmed Dede ve Melekzet'in eserinde 19 (on dokuz), Osman Dede'nin eserinde 16 (on alt1), Ali Dede, Raşit Efendi ve Mehmet Çelebi'nin eserinde 15 (on beş) adet geçki/çeşni kullanımı tespit edilmiştir. Gerçekleştirilen tahliller doğrultusunda, Rast makamında en çok kullanılan geçki/çeşnilerin Yegâh'da Rast, yerinde Uşşak, yerinde Segâh, yerinde Nikriz ve yerinde Hicaz olduğu sonucuna ulaşılmıştır. Rast makamının genel olarak Rast perdesini merkez alarak seyre başladığı ve Yegâh perdesi ile Tiz Hüseyni perdesi arasındaki ses sahasını kullandığı ortaya konulmuştur.

Rast makamına yönelik incelenen tüm makam tariflerinde makamın Rast perdesini merkez alarak seyre başlayacağına yönelik yer alan bilgiler ile elde edilen bulgular arasında benzerlik olduğu tespit edilmiştir. Rast makamında kullanılan ses sahası bakımından ise Abdülbâki Nasır 
Dede'nin tarifinde, kullanılacak en pest perdenin Yegâh perdesi olacağı hususundaki ifadesi örtüşürken, en tiz perdenin Gerdaniye perdesi olacağını tarif etmesiyle tiz taraftan genişleme konusunda yapmış olduğumuz tahliller ile örtüşmediği ortaya konulmuştur. Tanburi Cemil Bey ve Hüseyin Sadettin Arel'in pest taraftan genişleme hususunda tariflerindeki ile benzerlik göstermekte olup, tiz taraftan genişleme hususundaki tarifleri ile farklı noktaların olduğu tespit edilmiştir. Yakup Fikret Kutluğ'un makamın hem pest hem de tiz taraftaki genişlemeler hususundaki tarifleri ile benzerlik gösterdiği sonucuna varılmıştır. 19. yy. nazariyat kitaplarında Rast makamının geçki/çeşni kullanımına yönelik herhangi bir bilgi yer almadığı ortaya konulmuş olup, 20. yy. nazariyat kitaplarından Hüseyin Sadettin Arel ve Yakup Fikret Kutluğ'un bu hususta yer vermiş olduğu tarifler ile benzerlik gösterdiği sonucuna varılmıştır.

Rast makamına yönelik temel tartım kalıpları kullanılarak oluşturulan birinci etütte Rast perdesi merkez alınarak seyre başlanmış ve etüdün bütünü içerisinde Yegâh ile Tiz Segâh perdeleri arasındaki ses sahası kullanılmıştır. Birinci Rast etüt içerisinde; Yegâh'da Rast, yerinde Segâh, yerinde Uşşak, Hüseyniaşiran'da Uşşak, Nevâ'da Buselik, yerinde Araban, Çargâh'da Nikriz, yerinde Hüzzam, yerinde Nikriz, Hüseyniaşiran'da Karcığar ve yerinde Hicaz geçki/çeşnileri kullanılarak Rast makamına ait peşrevler içerisinde tespit edilen geçki/çeşnilere büyük oranda yer verilmiştir. Rast makamına yönelik farklı tartım kalıpları kullanılarak oluşturulan ikinci etütte Rast perdesi merkez alınarak seyre başlanmış ve etüdün bütünü içerisinde Yegâh ile Tiz Çargâh perdeleri arasındaki ses sahası kullanılmıştır. İkinci Rast etüt içerisinde ise; yerinde Segâh, yerinde Uşşak, Yegâh'da Rast, Hüseyniaşiran'da Uşşak, Nevâ'da Buselik, yerinde Hüzzam, yerinde Suzinak, yerinde Nikriz, Hüseyni'de Sabâ ve Hüseyni'de Uşşak geçki/çeşnileri kullanılmış olup, Rast makamına ait peşrevler içerisinde tespit edilen geçki/çeşnilere büyük oranda yer verilerek oluşturulmuştur.

\subsection{Ușşak Makamına İlişsin Sonuçlar}

Uşşak makamına yönelik peşrev formunda bestelenmiş 41 (kırk bir) eserden ulaşılabilen 35 (otuz beş) eser tespit edilmiştir. En çok geçki/çeşni kullanımı bakımından örneklem grubunda yer alan bu 10 (on) eserden Bestekârı belirli olmayan eserde 22 (yirmi iki), Bestekârı belirli olmayan eserde 20 (yirmi), Osman Bey'in eserinde 18 (on sekiz), Farabi'nin eserinde 14 (on dört), Bestekâr1 belirli olmayan eserde 13 (on üç), Haydar Tatlıyay ve Tatyos Efendi'nin eserinde 12 (on iki), Sultan I. Mahmud'un eserinde 11 (on bir), Corci'nin eserinde 10 (on), Salih Efendi'nin eserinde 9 (dokuz) adet geçki/çeşni kullanımı tespit edilmiştir. Gerçekleştirilen tahliller doğrultusunda, Uşşak makamında en çok kullanılan geçki/çeşnilerin yerinde Rast, Yegâh'da Rast, Hüseyni'de Uşşak, Nevâ'da Rast ve yerinde Segâh olduğu ortaya konulmuştur. Uşşak makamının genel olarak Dügâh perdesini merkez alarak seyre başladığı ve Yegâh perdesi ile Tiz Nevâ perdesi arasındaki ses sahasını kullandığı sonucuna varılmıştır.

Uş̧̧ak makamına yönelik incelenen Haşim Bey, Tanburi Cemil Bey, Hüseyin Sadettin Arel, Ekrem Karadeniz ve Yakup Fikret Kutluğ'un tariflerinde makamın Dügâh perdesini merkez alarak seyre başlayacağına yönelik yer alan bilgiler ile elde edilen bulgular arasında benzerlik göstermekte olup, Abdülbâki Nasır Dede'nin tarifi ile farklı noktaların olduğu tespit edilmiştir. Uşşak makamında kullanılan ses sahası bakımından ise Yakup Fikret Kutluğ ve Tanburi Cemil Bey'in tarifi ile benzerlik göstermekte olup, incelenen diğer makam tariflerinde bu husus ile ilgili farkl11kkların olduğu sonucuna ulaşılmıştır. 19. yy. nazariyat kitaplarında Uşşak makamının geçki/çeşni kullanımına yönelik herhangi bir bilgi yer almadığ 1 ortaya konulmuş olup, 20. yy. nazariyat kitaplarından Hüseyin Sadettin Arel ve Yakup Fikret Kutluğ'un bu hususta yer vermiş olduğu tarifler ile benzerlik gösterdiği sonucuna varılmıştır.

Uşşak makamına yönelik temel tartım kalıpları kullanılarak oluşturulan birinci etütte Dügâh perdesi merkez alınarak seyre başlanmış ve etüdün bütünü içerisinde Yegâh ile Tiz Nevâ perdeleri arasındaki ses sahası kullanılmıştır. Birinci Uşşak etüt içerisinde; yerinde Rast, Yegâh'da Rast, yerinde Segâh, Eviç'de Eviç/Segâh, Hüseyni'de Uşşak, yerinde Araban, yerinde Karcığar, 
yerinde Sabâ, Gerdaniye'de Buselik ve Nevâ'da Rast geçki/çeşnileri kullanılarak Uşşak makamına ait peşrevler içerisinde tespit edilen geçki/çeşnilere büyük oranda yer verilmiştir. Uşşak makamına yönelik farklı tartım kalıpları kullanılarak oluşturulan ikinci etütte Dügâh perdesi merkez alınarak seyre başlanmış ve etüdün bütünü içerisinde Kaba Nim Hicaz ile Tiz Nevâ perdeleri arasındaki ses sahası kullanılmıştır. İkinci Uşşak etüt içerisinde ise; yerinde Rast, Yegâh'da Rast, Gerdaniye'de Buselik, yerinde Segâh, yerinde Suzinak, Hüseyni'de Uşşak, Nevâ'da Rast, yerinde Hicaz, Yegâh'da Buselik, Gerdaniye'de Rast, Nevâ'da Buselik, Hüseyniaşiran'da Uşşak ve yerinde Hüzzam geçki/çeşnileri kullanılarak Uşşak makamına ait peşrevler içerisinde tespit edilen geçki/çeşnilere büyük oranda yer verilmiştir.

\section{Kaynakça}

Bardakçı, M. (2012). Refik Fersan ve hatıraları. Pan Yayıncılık.

Başer, F. A. (2013). Türk Mûsikîsinde Abdülbâki Nâsır Dede. Konservatuvar Müdürlüğü Yayınları.

Behar, C. (2012). Aşk olmayınca meşk olmaz. Yapı Kredi Yayınları.

Bilgin, N. (2006). Sosyal bilimlerde içerik analizi teknikler ve örnek çalı̧̧malar. Siyasal Kitabevi.

Bükülmez, H. (2019). Türk müziği keman icracıllğında ekol olmuş iki usta isim: Haydar Tatllyay ve Sadi Işıllay. Gece Kitaplığı.

Büyüköztürk, Ş., Çakmak, E. K., Akgün, Ö. E., Karadeniz, Ş. \& Demirel F. (2014). Bilimsel araştırma yöntemleri. Pegem Akademi.

Cevher, H. (1992). Tanburi Cemil Bey ve "Rehber-i Mûsikî", [Yayımlanmamış doktora tezi]. Ege Üniversitesi Sosyal Bilimler Enstitüsü.

Creswell, J. W. (2014). Araştırma deseni, nitel, nicel ve karma yöntem yaklaşımları. S. B. Demir (Ed.) (4. Bask1). Eğiten Kitap.

Hatipoğlu, V. (2013). Rast makamındaki kâr-ı nâtık eserlerinden oluşturulan seyr-i nâtık örneğinin keman ögretiminde kullanılabilirliğinin değerlendirilmesi, [Yayımlanmamış doktora tezi]. Gazi Üniversitesi Eğitim Bilimleri Enstitüsü.

Hatipoğlu, V. (2016). Türk müziği keman öğretimine yönelik yeni kaynak hazırlamada "Beylik Aranağmelerden" oluşturulan çeşitlemelerin yeri ve öneminin değerlendirilmesi, Turkish Studies, 11(19), 417-442. http://dx.doi.org/10.7827/TurkishStudies.1128

Hatipoğlu, V. (2017). Beylik Aranağme ve çeşitlemeleriyle Türk müziği keman alıştırmaları. Gece Kitaplı̆̆1.

Hatipoğlu, V. (2018). Mustafa Sunar'ın 'Alaturka Keman Muallimi' isimli öğretim kaynağının incelenmesi, Uluslararası Sosyal Araştırmalar Dergisi, 11(55), 605-621.

Karadeniz, E. (1965). Türk musikîsinin nazariye ve esasları. Türkiye İş Bankası Kültür Yayınları.

Karasar, N. (2005). Bilimsel araştırma yöntemi. Nobel Yayıncılık.

Kutluğ, Y. F. (2000). Türk musikisinde makamlar, Yapı Kredi Yayınları.

Özalp, N. (2000). Türk mûsikîsi tarihi. Millî Eğitim Bakanlığı Yayınları.

Özkan, İ. H. (2016). Türk mûsıkîsi nazariyatı ve usûlleri. Ötüken Yayınları. 
Şen, S. S. (1992). Evrensel keman teknikleri kullanılarak Türk folkloruna ve evrensel müziğe dayalı özgün keman etütlerinin yaratılması, [Yayımlanmamış doktora tezi]. Marmara Üniversitesi Fen Bilimleri Enstitüsü.

Tırışkan, A. G. (2000). Hâşim Bey'in edvârı, [Yayımlanmamış doktora tezi]. İstanbul Teknik Üniversitesi Sosyal Bilimleri Enstitüsü.

Yıldırım, A. \& Şimşek, H. (2011). Sosyal bilimlerde nitel araştırma yöntemleri. Seçkin Yayıncılık. 


\section{EKLER}

\begin{tabular}{|c|c|c|c|c|}
\hline Sira No & Arsiv No & Bestekâr & Makam & Usûl \\
\hline 1. & E2453 & - & Rast & Devr-i Revan \\
\hline 2. & E2454 & - & Rast & Nim Sakil-Değişmeli \\
\hline 3. & - & - & Rast & Düyek \\
\hline 4. & - & - & Rast & Sofyan \\
\hline 5. & - & - & Rast & Devr-i Kebir \\
\hline 6. & - & - & Rast & Sakil \\
\hline 7. & - & - & Rast & Düyek \\
\hline 8. & - & - & Rast & Düyek \\
\hline 9. & - & - & Rast & Düyek \\
\hline 10. & - & Ahmet Bey & Rast & Çenber \\
\hline 11. & - & Ahmet Bey & Rast & Düyek \\
\hline 12. & E2457 & Ahmet Bey & Rast & Fahte \\
\hline 13. & E2472 & Ahmet Bey & Rast & Ağır Düyek \\
\hline 14. & E2458 & Akın Özkan & Rast & Sakil \\
\hline 15. & - & Ali Dede & Rast & Devr-i Kebir \\
\hline 16. & E2485 & Ali Dede & Rast & Düyek \\
\hline 17. & E2484 & Ali Dede & Rast & Devr-i Kebir \\
\hline 18. & E2459 & - & Rast & Berefşan \\
\hline 19. & E2464 & Asım Bey & Rast & Devr-i Kebir \\
\hline 20. & - & Baba Ferruh & Rast & Sakil \\
\hline 21. & - & Baba Zeytun & Rast & Devr-i Kebir \\
\hline 22. & E2479 & Çengi Yusuf Dede & Rast & Darb-1 Fetih \\
\hline 23. & - & Çoban Giray & Rast & Devr-i Kebir \\
\hline 24. & - & Edhem Efendi & Rast & Devr-i Kebir \\
\hline 25. & - & Elçi & Rast & Havi \\
\hline 26. & E2500 & Emin Ağa & Rast & Hafif \\
\hline 27. & E0526 & Farabi & Rast & Çifte Düyek \\
\hline 28. & E2463 & - & Rast & Çifte Düyek \\
\hline 29. & - & Fethi Karamahmudoğlu & Rast & Berefşan \\
\hline 30. & E2465 & Handan Ă̆a & Rast & Düyek \\
\hline 31. & E2460 & Hasan Ağa & Rast & Sakil \\
\hline 32. & E2467 & Hüseyin Dede & Rast & Düyek \\
\hline 33. & & İrfan Özbakır & Rast & Sofyan \\
\hline 34. & E2475 & İsmet Ağa & Rast & Devr-i Kebir \\
\hline 35. & & Itri & Rast & Firengifer-Berefşan \\
\hline 36. & E2468 & Kantemiroğlu & Rast & Düyek \\
\hline 37. & & Kantemiroğlu & Rast & Berefşan \\
\hline 38. & E2470 & - & Rast & Berefşan \\
\hline 39. & E2471 & - & Rast & Düyek \\
\hline 40. & E2486 & Mehmet Dede & Rast & Ağır Düyek \\
\hline 41. & E2497 & Mehmet Hemdemi Efendi & Rast & Fahte \\
\hline 42. & - & Mehmet Hemdemi Efendi & Rast & Darb-1 Fetih \\
\hline 43. & - & Mehmet Reşat Aysu & Rast & Sofyan \\
\hline 44. & - & Melek Can & Rast & Çenber \\
\hline 45. & E2478 & Musi- Haham Moşe Faro & Rast & Muhammes \\
\hline 46. & E2461 & Mustafa & Rast & Evsat \\
\hline 47. & E2480 & Muzaffer & Rast & Darb-1 Fetih \\
\hline 48. & - & Muzaffer & Rast & Fahte \\
\hline 49. & E2481 & Muzaffer & Rast & Zincir \\
\hline 50. & E2482 & Mümin Ağa & Rast & Darbeyn \\
\hline 51. & - & Namık Kemal Aktan & Rast & Sofyan \\
\hline
\end{tabular}




\begin{tabular}{|c|c|c|c|c|}
\hline 52. & E2491 & Nedim Ağa & Rast & Fahte \\
\hline 53. & E2488 & Osman Dede & Rast & Darb-1 Fetih \\
\hline 54. & E2489 & Osman Dede & Rast & Düyek \\
\hline 55. & E2615 & Osman Dede & Rast & Çenber \\
\hline 56. & E2490 & Osman Dede & Rast & Devr-i Kebir \\
\hline 57. & - & Osman Paşa & Rast & Düyek \\
\hline 58. & E2487 & Raşit Efendi & Rast & Devr-i Kebir \\
\hline 59. & - & Akif Dede & Rast & Düyek \\
\hline 60. & - & Refik Fersan & Rast & Muhammes \\
\hline 61. & E2492 & Refik Fersan & Rast & Hafif \\
\hline 62. & E2493 & Reftar Kalfa & Rast & Çifte Düyek \\
\hline 63. & E2494 & Saffet Bey & Rast & Çifte Düyek \\
\hline 64. & E2495 & Selim Dede & Rast & Çenber \\
\hline 65. & E2496 & Sırrı Abdülbaki Dede & Rast & Çifte Düyek \\
\hline 66. & E2498 & Sulan III. Selim & Rast & Havi \\
\hline 67. & E2499 & Sultan III. Selim & Rast & Düyek \\
\hline 68. & - & Sultan IV. Murat & Rast & Devr-i Kebir \\
\hline 69. & - & Şakir & Rast & Sofyan \\
\hline 70. & - & Şerif & Rast & Darb-1 Fetih \\
\hline 71. & - & Şerif & Rast & Zincir \\
\hline 72. & - & Şerif & Rast & Çenber \\
\hline 73. & - & Şeyh & Rast & Düyek \\
\hline 74. & E2501 & Tatyos Efendi & Rast & Hafif \\
\hline 75. & E2502 & Veli Dede & Rast & Darbeyn \\
\hline 76. & E2503 & Yahya Çelebi & Rast & Hafif \\
\hline 77. & E2504 & Yusuf Paşa & Rast & Devr-i Kebir \\
\hline 78. & E2405 & - & Rast & Ağır Düyek \\
\hline 79. & - & Zeki Duygulu & Rast & Sofyan \\
\hline 80. & E2483 & Ali Dede & Rast & Devr-i Kebir \\
\hline 81. & - & - & Rast & Kürd Düyeği \\
\hline 82. & E2466 & Hüseyin Dede & Rast & Düyek \\
\hline 83. & E2476 & İsmail Hakkı Bey & Rast & Çenber \\
\hline 84. & E2477 & İsmail Hakkı Bey & Rast & Evsat \\
\hline 85. & E2474 & Mercan Dede & Rast & Düyek \\
\hline 86. & - & - & Rast & Düyek \\
\hline 87. & E2462 & Farabi & Rast & Berefşan \\
\hline 88. & E2473 & Mehmet Çelebi & Rast & Düyek \\
\hline 89. & E2469 & Melekzet & Rast & Devr-i Kebir \\
\hline 90. & - & Cinuçen Tanrıkorur & Rast & Sofyan \\
\hline
\end{tabular}

Ek 2 - Uşşak makamına ait peşrevler

\begin{tabular}{|c|c|c|c|c|}
\hline Sira No & Arşiv No & Bestekâr & Makam & Usûl \\
\hline 1. & - & - & Uşşak & Çifte Düyek \\
\hline 2. & E3318 & - & Uşşak & Berefşan \\
\hline 3. & E3319 & - & Uşşak & Çifte Düyek \\
\hline 4. & - & - & Uşşak & Darb-1 Fetih \\
\hline 5. & E3321 & - & Uşşak & Muhammes \\
\hline 6. & E3320 & - & Uşşak & Sakil \\
\hline 7. & - & Ahmet Hatipoğlu & Uşşak & Sofyan \\
\hline 8. & E3323 & Akın Özkan & Uş̧sak & Devr-i Kebir \\
\hline 9. & E3339 & Ali Rıza Efendi & Uşşak & Devr-i Kebir \\
\hline 10. & E3324 & Corci & Uşşak & Devr-i Kebir \\
\hline 11. & E3329 & Çoban Giray & Uşşak & Çenber \\
\hline 12. & E3330 & Çoban Giray & Uşşak & Evsat \\
\hline
\end{tabular}




\begin{tabular}{|c|c|c|c|c|}
\hline 13. & E3327 & Derviş Ali Rıza & Uşşak & Muhammes \\
\hline 14. & - & Emin Akan & Uşşak & Düyek \\
\hline 15. & E3328 & Farabi & Uşşak & Çifte Düyek \\
\hline 16. & - & Handan Ağa & Uşşak & Çenber \\
\hline 17. & E3333 & Haydar Tatliyay & Uşşak & Düyek \\
\hline 18. & E3331 & Hüseyin Sadettin Arel & Uşşak & Firenkçin \\
\hline 19. & E3332 & Hüseyin Sadettin Arel & Uşşak & Sofyan \\
\hline 20. & E3334 & - & Uşşak & Çenber \\
\hline 21. & - & - & Uşşak & Berefşan \\
\hline 22. & E3344 & İsak Efendi & Uşşak & Çenber \\
\hline 23. & E3337 & İsmail Hakk1 Bey & Uşşak & Çifte Düyek \\
\hline 24. & E3336 & Kantemiroğlu & Uşşak & Darb-1 Fetih \\
\hline 25. & - & - & Uşşak & Hafif \\
\hline 26. & E3335 & - & Uşşak & Çifte Düyek \\
\hline 27. & - & Mehmet Hemdemi Efendi & Uşşak & Devr-i Kebir \\
\hline 28. & - & Mehmet Hemdemi Efendi & Uşşak & Sakil \\
\hline 29. & - & Mehmet Hemdemi Efendi & Uşşak & Hafif \\
\hline 30. & - & Mehmet Hemdemi Efendi & Uşşak & Düyek \\
\hline 31. & E3338 & Mümin Dede & Uşşak & Çenber \\
\hline 32. & E3345 & Osman Bey & Uşşak & Muhammes \\
\hline 33. & E3340 & Osman Dede & Uşşak & Devr-i Kebir \\
\hline 34. & E3325 & Said Efendi & Uşşak & Çifte Düyek \\
\hline 35. & E3326 & Salih Efendi & Uşşak & Devr-i Kebir \\
\hline 36. & E3342 & Sultan I. Mahmud & Uşşak & Devr-i Kebir \\
\hline 37. & E3343 & Sultan III. Selim & Uşşak & Devr-i Kebir \\
\hline 38. & - & Şerif & Uşşak & Muhammes \\
\hline 39. & E3346 & Tatyos Efendi & Uşşak & Devr-i Kebir \\
\hline 40. & E3388 & Kantemiroğlu & Uşşak & Havi \\
\hline 41. & E3341 & Sultan I. Mahmud & Uşşak & Darbeyn \\
\hline
\end{tabular}

